\title{
Phosphine Oxide Catalyzed, Tetrachlorosilane-Mediated Enantio- selective Direct Aldol Reactions of Thioesters
}

\author{
Sergio Rossi* \\ Rita Annunziata \\ Franco Cozzi \\ Laura Maria Raimondi
}

Dipartimento di Chimica, Universita degli Studi di Milano, via Golgi 19, 20133 Milano, Italy

sergio.rossi@unimi.it

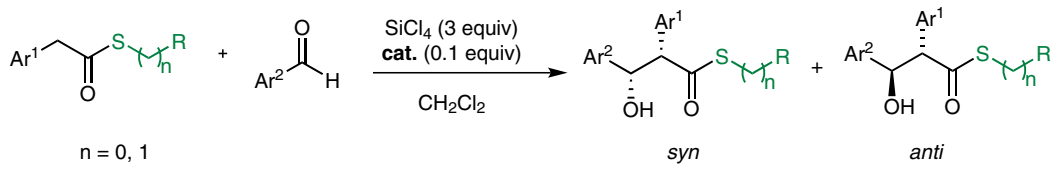

(O)

(R)-BINAPO

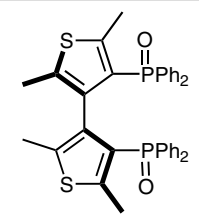

(S)-TetraMe-BITIOPO
Received: 09.02.2015

Accepted after revision: 24.03.2015

Published online: 13.05 .2015

DOI: 10.1055/s-0034-1379914; Art ID: ss-2015-t0066-op

Abstract The stereoselective direct aldol reaction of S-phenyl thioesters and aromatic aldehydes promoted by tetrachlorosilane was realized for the first time; the proposed mechanism involves the formation of a chiral cationic hypervalent silicon species and requires the presence of catalytic amounts of a Lewis base, like a chiral phosphine oxide. The reaction affords syn $\beta$-hydroxy thioesters as major isomers in good yields, high diastereoselectivity (up to $99: 1$ ), and up to $92 \%$ enantiomeric excess. The absolute configuration of the major isomer was established by converting the product into the corresponding $\beta$-hydroxy ester. The scope of the reaction was also investigated by employing differently substituted thioesters in combination with different aromatic aldehydes.

Key words asymmetric catalysis, direct aldol reaction, hypercoordinate silicon, phosphine oxides, thioesters

The use of tetrachlorosilane in combination with catalytic amounts of chiral Lewis bases to promote stereoselective reactions is nowadays a well-established method. ${ }^{1}$ Generally, the coordination of a Lewis base to a Lewis acid leads to the formation of a stable and less reactive adduct. However, in some circumstances, this adduct presents enhanced reactivity, as in the case of the coordination of a chiral Lewis base to a molecule of $\mathrm{SiCl}_{4}$, where a new silicon species with increased Lewis acidity is generated in situ. ${ }^{2}$

Due to its low cost and ready availability, the activation of tetrachlorosilane through the generation of hypervalent, highly reactive, silicate species can play an important role in the development of new, highly chemically and stereochemically efficient catalytic systems of low environmental impact. $^{3}$

In this field, a real breakthrough was achieved by Denmark, who developed phosphoramide-catalyzed and $\mathrm{SiCl}_{4}$-mediated stereoselective reactions. ${ }^{1 \mathrm{a}}$ The coordination of the chiral Lewis base to $\mathrm{SiCl}_{4}$ generates a new hypervalent ${ }^{4}$ silicon species of increased acid character, responsible for the addition of different nucleophiles to carbonyl compounds with high chemical and stereochemical efficiency. These studies opened the way to the so-called 'Lewis base catalyzed Lewis acid mediated reactions' where chiral phosphoroamides, ${ }^{10,5}$ phosphine oxides, ${ }^{1 b, c, 6}$ and sulfoxides ${ }^{7}$ have found extensive application as Lewis bases for the activation of trichlorosilyl derivatives, including tetrachlorosilane.

In 2011, our group reported the first organocatalytic direct aldol addition of activated thioesters to aldehydes, catalyzed by phosphine oxides and mediated by the presence of $\mathrm{SiCl}_{4}{ }^{8}$ Based on this method, activated fluorinated thioesters act as nucleophiles and react with aromatic aldehydes, leading to the formation of $\beta$-hydroxy thioesters in good yield and high diastereo- and enantioselectivity, up to 95\% ee (Scheme 1, a).

Before our contribution, the use of activated fluorinated thioesters ${ }^{9}$ or malonic acid half thioesters ${ }^{10}$ as ester mimics was limited only to a few examples of nonstereoselective Mannich transformations and enantioselective Michaeltype reactions, and no examples of direct aldol-type reaction were known. On the other hand, a few examples of organocatalytic, nonstereoselective, direct aldol reaction with carboxylic acid derivatives were known. ${ }^{11}$ In 2013, List and Song ${ }^{12}$ reported an organocatalytic enantioselective decarboxylative aldol reaction of malonic acid half thioesters with aldehydes using a cinchona-based sulfonamide, and very recently Wang ${ }^{13}$ reported an enantioselective cascade reaction between $\alpha, \beta$-unsaturated aldehydes and malonic half thioesters for the synthesis of chiral $\delta$-lactones promoted by a prolinol-derived catalyst.

The use of activated fluorinated thioesters rather than malonic half thioesters offers the possibility to obtain highly functionalized products with more efficient atom econo- 
a) previous work<smiles>O=CCC(=O)SCC(F)(F)F</smiles>

b) this work<smiles>[R]CSC(=O)C[Al]</smiles><smiles>[14CH3]C=O</smiles>
$\mathrm{SiCl}_{4}$ (3 equiv)
cat. (0.1 equiv)

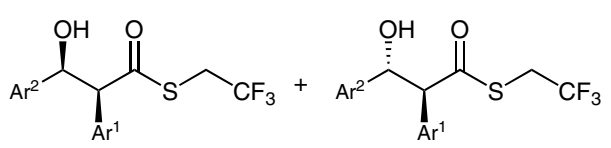

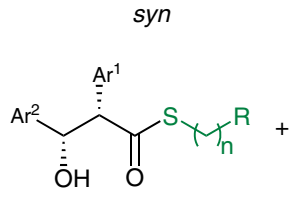<smiles>O=C(O)SC(=O)C(Br)C(O)Br</smiles><smiles>O=P(O)(c1ccccc1)c1ccc2ccccc2c1-c1c(P(=O)(c2ccccc2)c2ccccc2)ccc2ccccc12</smiles>

1

(R)-BINAPO

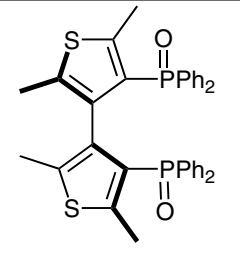

(S)-TetraMe-BITIOPO

Scheme 1 Direct aldol reaction of thioesters with aromatic aldehydes catalyzed by phosphine oxides

my through a straightforward procedure. Despite its potentiality, the direct aldol reaction of thioesters suffers mainly from two drawbacks: (1) trifluoroethanethiol used to synthetize the thioester is expensive and (2) the presence of an aryl group at the $\alpha$-position is necessary to activate the substrate and make the organocatalytic approach feasible.

The possibility to use cheaper and more environmentally friendly starting materials for this fundamental transformation is of course very attractive; we now wish to report the results of our investigation on the use of simple, easily available thioester substrates in the organocatalytic direct aldol reaction (Scheme $1, \mathrm{~b}$ ).

In order to extend the applicability of the direct aldol reaction of thioesters with aldehydes, the substitution of the activating trifluoroethylthio moiety with other substituents was performed, taking into consideration the reactivity scale depicted in Figure $1 . .^{\mathrm{b}, 14}$

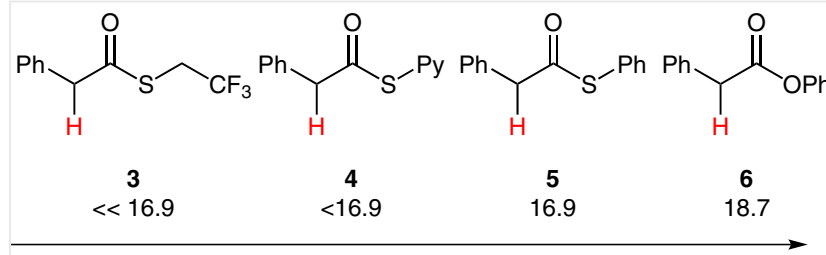

$\mathrm{p} K_{\mathrm{a}}$ in DMSO (decreasing reactivity)

Figure $1 \mathrm{p} K_{\mathrm{a}}$ values of the $\alpha$-protons of carboxylic acid derivatives in $\mathrm{DMSO}^{9 \mathrm{~b}, 14}$
It is known that esters are generally unreactive in organocatalysis due to the relatively low acidity of the proton at the $\alpha$-position of the ester function ( $\mathrm{p} K_{\mathrm{a}}=18.7$ for compound $\mathbf{6}$ ), and can be activated only by the presence of strong electron-withdrawing groups (as the $\mathrm{SCH}_{2} \mathrm{CF}_{3}$ group for compound 3). However, no information is reported about the reactivity of compounds $\mathbf{4}$ and $\mathbf{5}$ as potential nucleophiles in direct aldol addition reaction catalyzed by Lewis bases and promoted by silicon tetrachloride.

Following this approach, the $S$-(3,3,3-trifluoro)ethyl group of $\mathbf{3}$ was initially replaced with an $S$-pyridin-2-yl moiety. Thioester 4 was synthesized and employed in the direct aldol reaction with aromatic aldehydes in the presence of 3 equivalents of $\mathrm{SiCl}_{4}, 10$ equivalents of $i$ - $\mathrm{Pr}_{2} \mathrm{NEt}$ and 10 mol\% of $(R)$-BINAPO at $5{ }^{\circ} \mathrm{C}$ in $\mathrm{CH}_{2} \mathrm{Cl}_{2}$ as solvent (Scheme 2).

Disappointingly, $\beta$-hydroxy thioesters 7a,b were obtained with high diastereoselectivity, but in very low yields and no enantioselectivity. Hypothesizing that these unsatisfactory results could derive from the coordination of the pyridyl residue of the substrate to $\mathrm{SiCl}_{4}$ (causing a competitive interference with the formation of the catalytic hypervalent species), ${ }^{15}$ we envisioned that the replacement of the $S$-pyridin-2-yl moiety with the $S$-phenyl moiety could avoid this competitive coordination process. Thioester $\mathbf{5}$ was then synthesized in $80 \%$ yield by reaction of acyl chloride with thiophenol and reacted with benzaldehyde, in the presence of catalytic amounts of chiral phosphine oxide, under standard reaction conditions. ${ }^{16}$ Selected results are reported in Table 1. 


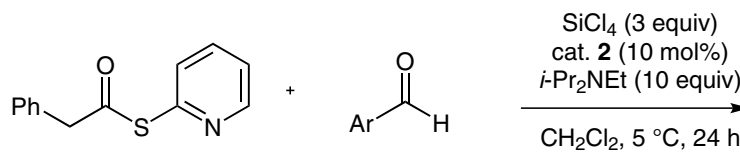

4
$\mathrm{Ar}=\mathrm{Ph}$

$\mathrm{Ar}=4-\mathrm{ClC}_{6} \mathrm{H}_{4}$<smiles>O=C(Sc1ccccn1)C(c1ccccc1)C(O)c1ccccc1</smiles><smiles>O=C(Sc1ccccn1)C(c1ccccc1)[C@H](O)[Al]</smiles>

7a: $14 \%>98: 2 \mathrm{dr}, \mathrm{rac}$ 7b: $15 \% 80: 20 \mathrm{dr}, \mathrm{rac}$

Scheme 2 Direct aldol reaction of pyridin-2-yl thioester with aromatic aldehydes

The reaction promoted by $(R)$-BINAPO $(\mathbf{1})$ led to the formation of the $\beta$-hydroxy thioester 8a in $70 \%$ yield, $66: 34$ syn/anti ratio, and $27 \%$ ee for the syn-enantiomer (Table 1 , entry 1). Lowering the temperature decreased the yield, but improved the enantioselection (entries 1 vs 2 and 3 vs 4 ). In addition, these preliminary studies confirmed that catalyst, (S)-TetraMe-BITIOPO (2), catalyzes the reaction with better chemical and stereochemical efficiency than $(R)$-BINAPO $(\mathbf{1})$, even if this difference could be observed only at lower temperature. ${ }^{8 a}$ Notably, at $0{ }^{\circ} \mathrm{C}$, the electron-rich dithiophene phosphine oxide $\mathbf{2}$ was able to promote the addition of the readily available $S$-phenyl thioester of phenylacetic acid 5 to benzaldehyde with good syn selectivity and 74\% enantioselectivity for the major isomer (entry 4). Considering the small difference in terms of reactivity of the two catalysts, we decided to employ phosphine oxide $\mathbf{2}$ in the survey of direct aldol addition of thioester $\mathbf{5}$ to substituted aromatic aldehydes.

Aldehydes bearing electron-donating groups afforded products with higher levels of diastereo- and enantioselectivity than electron-poor aldehydes. In addition, diastereoselection seems to be influenced by steric characteristics of the substrates: ortho-substituted aldehydes lead to the for- mation of corresponding $\beta$-hydroxy thioesters with syn/anti ratio ranging from 91:9 to $>99: 1$, even if in lower yields (Table 2, entries 6, 8, 9, 12).

The temperature plays an important role for the chemical and stereochemical outcome of the reaction: lowering the temperature increases the value of enantiomeric excess, but depresses the yield, and only with $20 \mathrm{~mol} \%$ of catalyst 2 satisfactory results were obtained (Table 2 , entry 3 ). Considering that yields are modest at $0{ }^{\circ} \mathrm{C}$, no further attempts were performed in terms of temperature variation.

3-Methylbenzaldehyde afforded the hydroxy thioester $8 \mathbf{e}$ in $80 \%$ yield, modest diastereoselectivity and $73 \%$ ee for the syn-diastereosiomer (Table 2, entry 7). 4-Trifluoromethylbenzaldehyde gave the product $8 \mathbf{i}$ in $76 \%$ yield and $41 \%$ ee (entry 11 ), while the analogous 4 -fluoro derivative $\mathbf{8 h}$ was isolated in 59\% yield and 68\% ee (entry 10 ).

Heteroaromatic aldehydes were also investigated and proved to be suitable substrates for the present method; product $\mathbf{8 n}$ derived by furfural was obtained in $76 \%$ yield, $84: 16$ syn/anti ratio and with $92 \%$ enantiomeric excess for the syn-distereoisomer. Finally, this method was applied to aliphatic aldehydes: as expected, no product was obtained with isobutyraldehyde (Table 2, entry 15), confirming that

Table 1 Aldol Condensation between Thioester 5 and Benzaldehyde

\begin{tabular}{|c|c|c|c|c|c|c|}
\hline & & & $\begin{array}{c}\mathrm{SiCl}_{4} \text { (3 equiv) } \\
\begin{array}{c}\text { cat. (10 mol\%) } \\
i-\mathrm{Pr}_{2} \mathrm{NEt}(10 \text { equiv) }\end{array} \\
\underset{\mathrm{CH}_{2} \mathrm{Cl}_{2}, 24 \mathrm{~h}}{\longrightarrow}\end{array}$ & $\begin{array}{c}\vdots \\
\dot{\mathrm{Ph}} \\
\mathbf{8 a}-s y n\end{array}$ & $\underbrace{\mathrm{OH}}_{\substack{\mathbf{P} h \\
\mathbf{8 a}-a n t i}}$ & \\
\hline Entry & Catalyst & Temp $\left({ }^{\circ} \mathrm{C}\right)$ & Yield (\%) & syn/antib & syn ee $(\%)^{c}$ & anti ee $(\%)^{c}$ \\
\hline 1 & $(R)-1$ & r.t. & 70 & $66: 34$ & $27(2 R, 3 R)$ & $60(2 R, 3 S)$ \\
\hline 2 & $(R)-1$ & 0 & 33 & $69: 31$ & $30(2 R, 3 R)$ & $68(2 R, 3 S)$ \\
\hline 3 & $(S)-2$ & r.t. & 67 & 41:59 & $22(2 S, 3 S)$ & $16(2 S, 3 R)$ \\
\hline 4 & (S)-2 & 0 & 62 & $71: 29$ & $74(2 S, 3 S)$ & $68(2 S, 3 R)$ \\
\hline $5^{d}$ & (S)-2 & 0 & 47 & $74: 26$ & $50(2 S, 3 S)$ & $73(2 S, 3 R)$ \\
\hline
\end{tabular}

a Yields were determined after chromatographic purification.

b Diastereoisomeric ratio was determined on the crude reaction product by ${ }^{1} \mathrm{H}$ NMR spectroscopy and confirmed by HPLC.

c The ee value was determined by HPLC on a chiral column.

d 1 equiv of thioester was used. 
Table 2 Aldol Condensation between Thioester $\mathbf{5}$ and Different Aldehydes

\begin{tabular}{|c|c|c|c|c|c|c|c|c|}
\hline & & & $\begin{array}{r}\mathrm{S} \\
\mathrm{ca} \\
i-\mathrm{Pr}_{2}\end{array}$ & $\begin{array}{l}\text { (3 equiv) } \\
10 \text { mol\%) } \\
=t \text { (10 equiv) } \\
\underset{\mathrm{Cl}_{2}, 24 \mathrm{~h}}{\longrightarrow}\end{array}$ & $\begin{array}{l}\overline{P h} \\
8-s\end{array}$ & & $\underbrace{O}_{\substack{\text { P. } \\
\text { P-anti }}}$ & \\
\hline Entry & $\mathrm{R}$ & Catalyst & Temp $\left({ }^{\circ} \mathrm{C}\right)$ & Product & Yield (\%) ${ }^{\mathrm{a}}$ & syn/antib & syn ee $(\%)^{c}$ & anti ee $(\%)^{c}$ \\
\hline 1 & $4-\mathrm{MeOC}_{6} \mathrm{H}_{4}$ & $(R)-1$ & r.t. & $8 b$ & 41 & $62: 38$ & $7(2 R, 3 R)$ & $17(2 R, 3 S)$ \\
\hline 2 & 4- $\mathrm{MeOC}_{6} \mathrm{H}_{4}$ & $(R)-1$ & 0 & $8 b$ & 27 & $80: 20$ & $50(2 R, 3 R)$ & $69(2 R, 3 S)$ \\
\hline $3^{d}$ & $4-\mathrm{MeOC}_{6} \mathrm{H}_{4}$ & $(S)-2$ & 0 & $8 b$ & 69 & $82: 18$ & $53(2 S, 3 S)$ & $66(2 S, 3 R)$ \\
\hline 4 & $4-\mathrm{ClC}_{6} \mathrm{H}_{4}$ & $(R)-1$ & r.t. & $8 c$ & 66 & $65: 35$ & $6(2 R, 3 R)$ & $11(2 R, 3 S)$ \\
\hline 5 & $4-\mathrm{ClC}_{6} \mathrm{H}_{4}$ & $(R)-1$ & 0 & $8 c$ & 45 & $58: 42$ & $6(2 R, 3 R)$ & $35(2 R, 3 S)$ \\
\hline 6 & 2- $\mathrm{MeC}_{6} \mathrm{H}_{4}$ & $(S)-2$ & 0 & $8 d$ & 35 & $92: 8$ & $69(2 S, 3 S)$ & $75(2 S, 3 R)$ \\
\hline 7 & 3- $\mathrm{MeC}_{6} \mathrm{H}_{4}$ & $(S)-2$ & 0 & $8 e$ & 80 & $67: 33$ & $73(2 S, 3 S)$ & $66(2 S, 3 R)$ \\
\hline 8 & $2,4,6-\mathrm{Me}_{3} \mathrm{C}_{6} \mathrm{H}_{2}$ & $(S)-2$ & 0 & $8 f$ & 58 & $>99: 1$ & $48(2 S, 3 S)$ & - \\
\hline 9 & 2,6-(MeO) $)_{2} \mathrm{C}_{6} \mathrm{H}_{3}$ & (S)-2 & 0 & $8 g$ & 61 & $92: 8$ & $91(2 S, 3 S)$ & $54(2 S, 3 R)$ \\
\hline 10 & 4- $\mathrm{FC}_{6} \mathrm{H}_{4}$ & $(S)-2$ & 0 & $8 \mathrm{~h}$ & 59 & $69: 31$ & $68(2 S, 3 S)$ & $65(2 S, 3 R)$ \\
\hline 11 & 4- $\mathrm{CF}_{3} \mathrm{C}_{6} \mathrm{H}_{4}$ & $(S)-2$ & 0 & $8 i$ & 76 & $75: 25$ & $41(2 S, 3 S)$ & $15(2 S, 3 R)$ \\
\hline 12 & 2- $\mathrm{NO}_{2} \mathrm{C}_{6} \mathrm{H}_{4}$ & $(S)-2$ & 0 & 81 & 67 & $91: 9$ & $29(2 S, 3 S)$ & nd \\
\hline 13 & 1-naphthyl & $(S)-2$ & 0 & $8 m$ & 44 & $69: 31$ & $51(2 S, 3 S)$ & $82(2 S, 3 R)$ \\
\hline 14 & 2-furyl & (S)-2 & 0 & $8 n$ & 76 & $84: 16$ & $92(2 S, 3 S)$ & $66(2 S, 3 R)$ \\
\hline 15 & $i-\operatorname{Pr}$ & $(S)-2$ & 0 & 80 & - & - & - & - \\
\hline
\end{tabular}

${ }^{a}$ Yields were determined after chromatographic purification.

${ }^{\mathrm{b}}$ Diastereoisomeric ratio was determined on the crude reaction product by ${ }^{1} \mathrm{H}$ NMR spectroscopy and confirmed by HPLC.

' The ee value was determined by HPLC on a chiral column.

d 1 equiv of thioester was used.

Table 3 Aldol Condensation between Substituted Thioester and Different Aldehydes

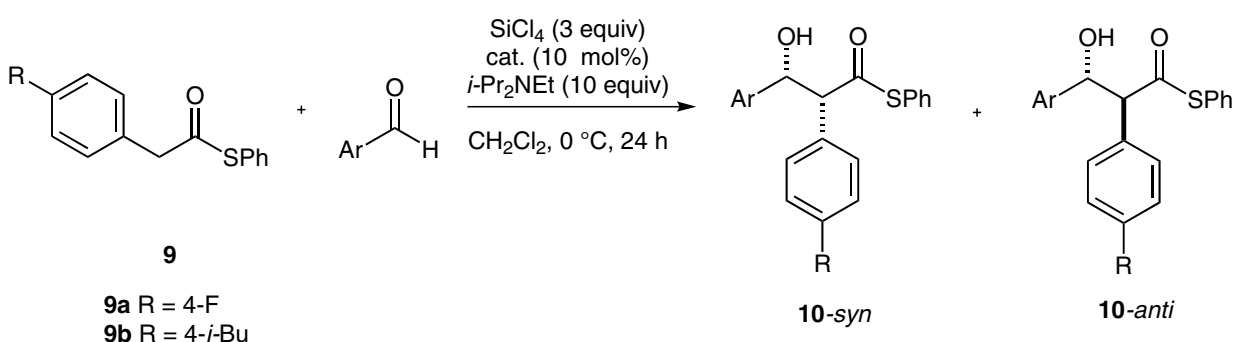

\begin{tabular}{|c|c|c|c|c|c|c|c|c|}
\hline Entry & $R$ & $\mathrm{Ar}$ & Catalyst & Product & Yield (\%) & syn/antib & syn ee $(\%)^{c}$ & anti ee $(\%)^{c}$ \\
\hline 1 & $\mathrm{~F}$ & $\mathrm{Ph}$ & $(R)-1$ & $10 a$ & 44 & $66: 34$ & $70(2 R, 3 R)$ & $13(2 R, 3 S)$ \\
\hline 2 & $\mathrm{~F}$ & $\mathrm{Ph}$ & (S)-2 & $10 a$ & 29 & $46: 54$ & $64(2 S, 3 S)$ & $63(2 S, 3 R)$ \\
\hline 3 & $i$-Bu & $\mathrm{Ph}$ & $(R)-1$ & $10 \mathrm{~b}$ & 46 & $73: 27$ & $22(2 R, 3 R)$ & $50(2 R, 3 S)$ \\
\hline 4 & $i-B u$ & $\mathrm{Ph}$ & (S)-2 & $10 \mathrm{~b}$ & 47 & $61: 39$ & $87(2 S, 3 S)$ & $43(2 S, 3 R)$ \\
\hline 5 & $i$-Bu & 4- $\mathrm{MeOC}_{6} \mathrm{H}_{4}$ & (S)-2 & $10 c$ & 43 & $83: 17$ & $85(2 S, 3 S)$ & $71(2 S, 3 R)$ \\
\hline 6 & $i-B u$ & $4-\mathrm{ClC}_{6} \mathrm{H}_{4}$ & (S)-2 & 10d & 59 & $87: 13$ & $65(2 S, 3 S)$ & $39(2 S, 3 R)$ \\
\hline
\end{tabular}

a Yields were determined after chromatographic purification.

${ }^{b}$ Diastereoisomeric ratio was determined on the crude reaction product by ${ }^{1} \mathrm{H}$ NMR spectroscopy and confirmed by HPLC

' The ee value was determined by HPLC on a chiral column. 
aliphatic aldehydes are less reactive in Lewis base catalyzed reactions. ${ }^{17}$

On the basis of these results we focused our attention on the use of substituted $S$-phenyl thioesters of arylacetic acids $\mathbf{9 a}, \mathbf{b}$ as substrates in the direct aldol reaction promoted by phosphine oxides (Table 3 ).

These results showed that starting from 4-fluorophenyl substituted thioester 9a, $\beta$-hydroxy thioester 10a was formed in $44 \%$ yield, $66: 34$ of syn/anti ratio, and $70 \%$ of enantiomeric excess for the syn-diastereoisomer using $(R)$ BINAPO (1) as catalyst (Table 3, entry 1 ). Comparable enantioselectivity was obtained using $(S)$-TetraMe-BITIOPO (2), even if with no diastereoselection (entry 2). Interestingly, thioester $\mathbf{9 b}$ reacts with benzaldehyde to give $\mathbf{1 0 b}$ in comparable yields in the presence of $(R)$-BINAPO (1) and $(S)$-TetraMe-BITIOPO (2). However, aldol products were obtained in higher enantioselectivity when phosphine oxide $\mathbf{2}$ was used (entry 3 vs 4); thus with 2 a remarkable level of enantioselectivity was reached ( $87 \%$ ee, entry 4 ,) The same high enantioselectivity was observed in the reaction with an electron-rich aldehyde ( $85 \%$ ee, entry 5 ), while the combination of thioesters $\mathbf{9 b}$ with electron-poor aldehydes gave $\beta$-hydroxy thioesters in higher yield and diastereoselection, but lower enantiocontrol (entry 6). This method was further successfully extended to less reactive thioesters, such as $S$-benzyl 2-phenylethanethioate (11). In this case, the formation of the corresponding $\beta$-hydroxy thioesters 12 could be achieved in modest diastereo- and enantioselectivity and in low yields. No product was observed instead when $S$-phenyl 3,3-dimethylbutanethioate (13) was used. Therefore, the reaction was not further studied in detail (Scheme 3).
The relative configuration of $\beta$-hydroxy thioesters $\mathbf{8}$ was established by converting the syn/anti mixture of product 8a (Table 1, entry 1) into the corresponding syn/anti mixture of the known $\beta$-hydroxy methyl ester 14 by reaction with $m$-CPBA and methanol in $\mathrm{CH}_{2} \mathrm{Cl}_{2}$ (Scheme 4). ${ }^{18}$ The syn/anti ratio was assigned on the basis of the methoxy groups signals in the ${ }^{1} \mathrm{H}$ NMR spectrum of the crude mixture. The 14-syn and 14-anti compounds were then separated by chromatographic purification, and the absolute configuration was determined to be $2 R, 3 R$ for the major syn enantiomer and $2 R, 3 S$ for the major anti enantiomer by comparison of the optical rotation values with those reported in literature. ${ }^{19}$ The configuration of the other compounds was assigned by analogy.

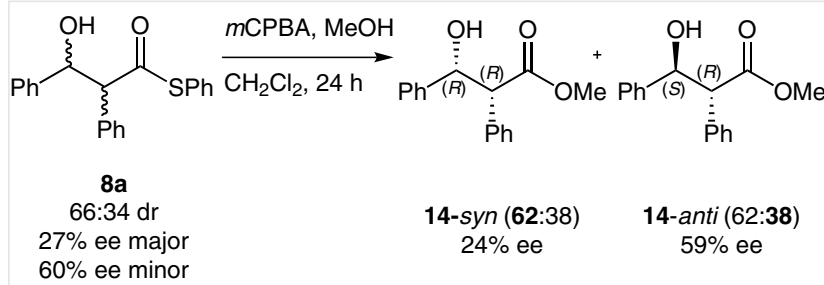

Scheme 4 Determination of relative and absolute configuration of $\beta$ hydroxy thioester 8

After the absolute configuration was determined, simple computational calculations were performed in order to elucidate the origin of stereoselectivity. The reaction between thioester $\mathbf{5}$ and benzaldehyde in the presence of tetrachlorosilane promoted by catalyst $\mathbf{2}$ was computationally studied. On the basis of steric considerations, adduct $\mathbf{I}$, formed upon coordination of thioester $\mathbf{5}$ with the chlorosilane species, will adopt a 'pinwheel' conformation to minimize the repulsion between bulky peripheral groups. ${ }^{20}$
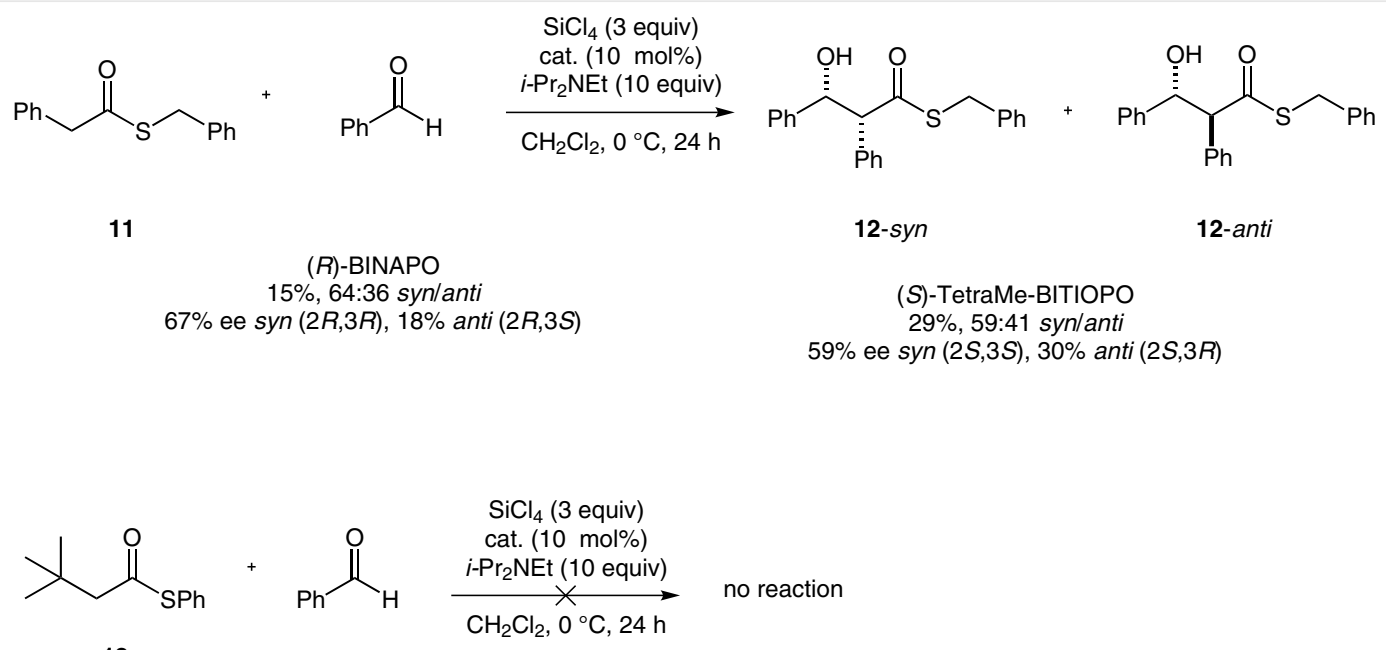

13

Scheme 3 Aldol condensation of S-benzyl thioester 

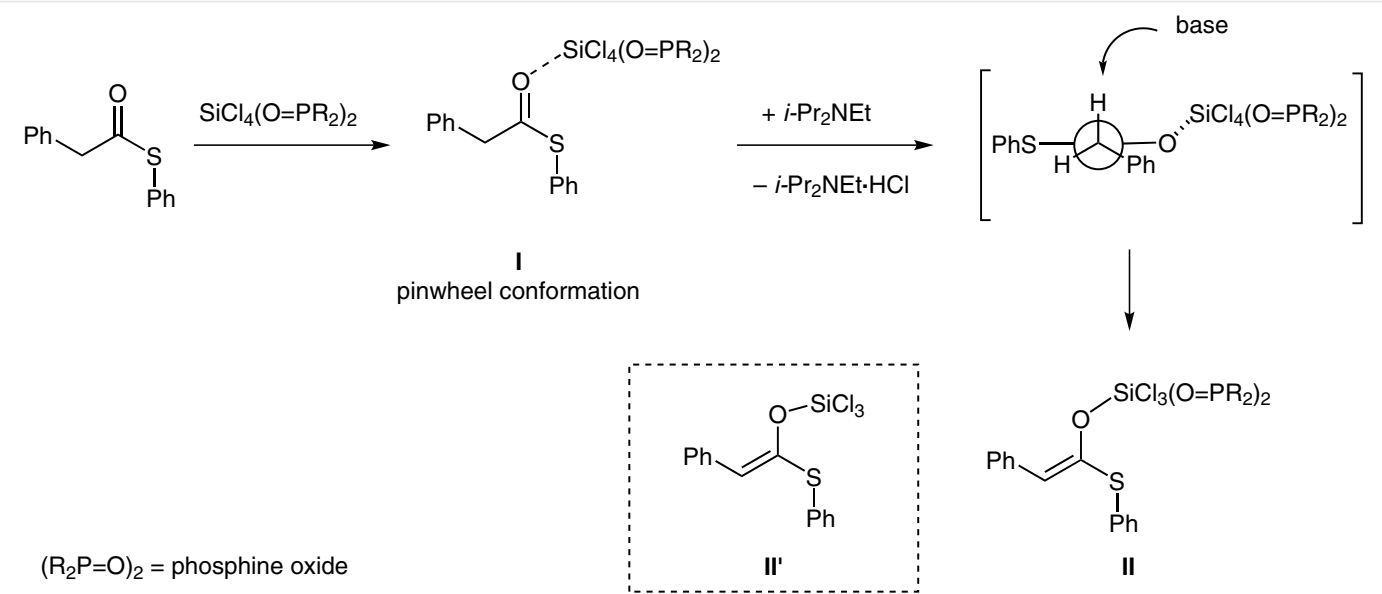

Scheme $\mathbf{5}$ Formation of the $\mathrm{O}$-silyl ketene thioacelal derived from compound $\mathbf{5}$

Deprotonation with a bulky base such as $i$ - $\operatorname{Pr}_{2} \mathrm{NEt}$ will afford the 0 -silyl ketene thioacetal II. In agreement with experimental observations, DFT calculations at B3LYP-631g level of theory confirmed that $(E)$-trichlorosilyl thioacetal II' (according to CIP rules) was more stable by $2.48 \mathrm{kcal} / \mathrm{mol}$ than the corresponding $Z$-isomer (Scheme 5).

From ketene thioacetal II, the formation of the aldol product is expected to occur via a Zimmerman-Traxler cationic chair-like transition structure ${ }^{21}$ where the aldehyde is coordinated - and, thus, activated - by the positively charged silicon atom (Scheme 6). The two transition states (TSs) responsible of the formation of syn- $\beta$-hydroxy thioesters were located and depicted in Scheme 6. Computationally, a conformational analysis with Monte Carlo technique was performed using MMFFs as force field with Macromodel Schrodinger suite package ${ }^{22}$ on a model of the TSs, obtained by constraining the two reacting atoms (the aldehyde electrophilic carbon and the 0 -silyl thioketene acetal nucleophilic $\alpha$-carbon) at about $2.3 \AA$ distance. In this way, the best arrangement for the different substituents around a model of the reaction moiety was obtained.

Subsequently, the two structures leading to the formation of the two syn products, were fully optimized to the relative genuine TSs with PM6 semiempirical methods (both with only one imaginary frequency). ${ }^{23}$ The calculations, performed using $(S)$-TetraMe-BITIOPO as catalyst, showed that TS-1, responsible of the formation of syn$(2 S, 3 S)$-diastereoisomer, was more stable by $0.40 \mathrm{kcal} / \mathrm{mol}$ than TS-2. A possible explanation of these slight differences in energy could be ascribed to the steric repulsions, observed in TS-2 between diphenylphosphinoyl group of the phosphine oxide $\mathbf{2}$ and the thiophenyl group of the $O$-silyl
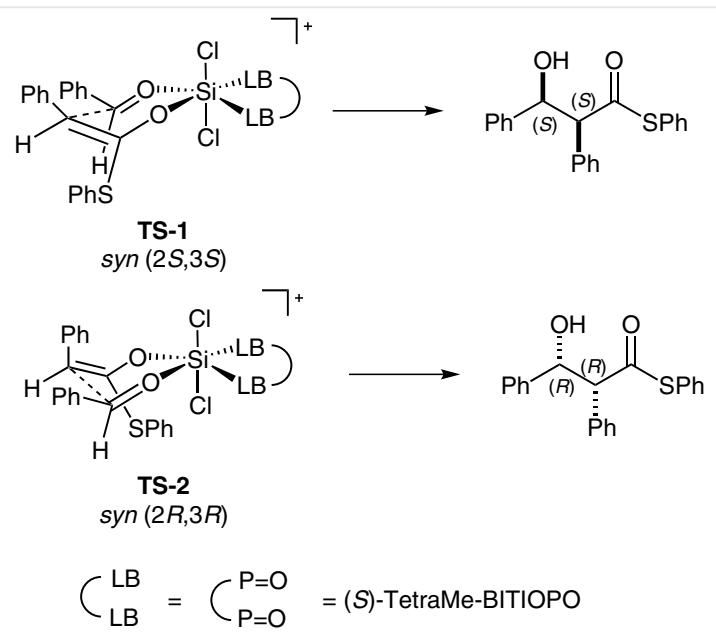

Scheme 6 Transition states responsible for the syn-stereoselection

ketene thioacetal that would be responsible for the favorable attack of the thioacetal onto the Si face of the aldehyde (Figure 2).

In conclusion, a direct, organocatalytic addition of readily available thioesters to aldehydes catalyzed by a chiral cationic hypervalent silicon species has been developed. The reaction of $S$-phenyl $\alpha$-arylthioesters with aromatic aldehydes in the presence of a catalytically amount of a chiral phosphine oxide and a stoichiometric amount of tetrachlorosilane led to the formation of the corresponding $\beta$-hydroxy thioesters in modest yields (up to $70 \%$ ), good syn/anti ratio (up to $82: 18$ ), and in up to $87 \%$ enantiomeric excess. Further experiments are ongoing in our group to extend the applicability of this method, as well as to improve the chemical efficiency of this transformation. 

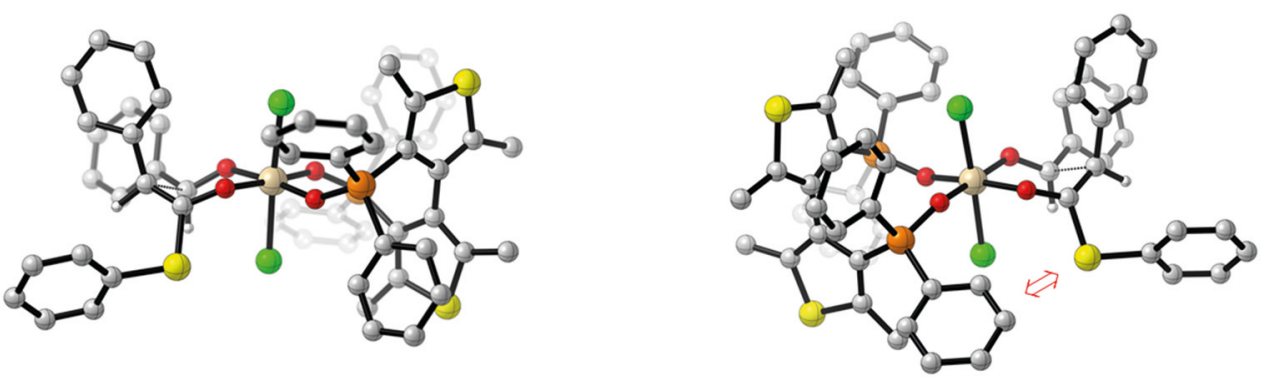

TS-1 syn $(2 S, 3 S)$ $0 \mathrm{kcal} / \mathrm{mol}$ TS-2 syn $(2 R, 3 R)$
$+0.40 \mathrm{kcal} / \mathrm{mol}$
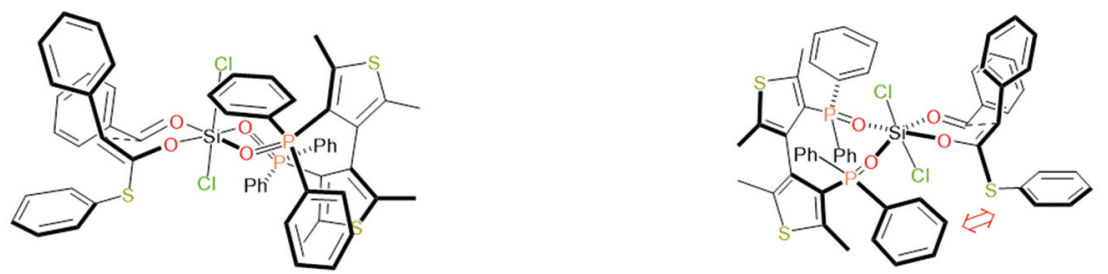

Figure 2 Calculated transition state geometries (hydrogens are omitted for clarity)

All reactions were carried out in oven-dried glassware with magnetic stirring under a nitrogen atmosphere, unless otherwise stated. Anhydrous solvents were purchased and stored under nitrogen over molecular sieves (bottles with crown caps). Reactions were monitored by analytical TLC using silica gel 60 F254 precoated glass plates $(0.25$ $\mathrm{mm}$ thickness) and visualized using UV light or with phosphomolybdic acid. ${ }^{1} \mathrm{H}$ NMR spectra were recorded on spectrometers operating at $300 \mathrm{MHz}$ (Bruker Fourier 300 or AMX 300). The ${ }^{1} \mathrm{H}$ NMR chemical shifts are reported in ppm $(\delta)$ with the solvent reference relative to TMS as the internal standard $\left(\mathrm{CDCl}_{3}, \delta=7.26\right) .{ }^{13} \mathrm{C}$ NMR spectra were recorded on $300 \mathrm{MHz}$ spectrometers (Bruker Fourier 300 or AMX 300 ) operating at $75 \mathrm{MHz}$, with complete proton decoupling. ${ }^{13} \mathrm{C}$ NMR chemical shifts are reported in ppm $(\delta)$ relative to TMS with the respective solvent resonance as the internal standard $\left(\mathrm{CDCl}_{3}, \delta=77.0\right)$. ${ }^{19} \mathrm{~F}$ NMR spectra were recorded on $300 \mathrm{MHz}$ spectrometers (Bruker AMX 300) operating at $282 \mathrm{MHz} .{ }^{19} \mathrm{~F}$ NMR chemical shifts are reported in ppm $(\delta)$ relative to $\mathrm{CF}_{3} \mathrm{Cl}$. Optical rotations were obtained on a polarimeter at $589 \mathrm{~nm}$ using a $5 \mathrm{~mL}$ cell with a length of $1 \mathrm{dm}$. HPLC for ee determinations was performed under the conditions reported below using Agilent 1100 or 1200 series. All melting points are uncorrected and were obtained using an Electrothermal IA9100 digital melting point apparatus.

\section{Thioester Condensation; General Procedure}

The acid ( 1 equiv, $2.5 \mathrm{mmol}$ ) and thiophenol (1.1 equiv, $2.75 \mathrm{mmol}$ ) were dissolved in anhydrous THF $(5 \mathrm{~mL})$ and cooled to $0{ }^{\circ} \mathrm{C}$; then $N, N^{\prime}-$ dicyclohexylcarbodiimide (DCC; 1 equiv, $2.5 \mathrm{mmol}$ ) was added. The reaction was monitored by TLC (eluent: using hexane-EtOAc, 95:5) and after $24 \mathrm{~h}$, the crude mixture was filtered and the solvent was removed under reduced pressure. The crude product was purified by flash chromatography.

\section{S-Phenyl 2-(4-Fluorophenyl)ethanethioate (9a)}

2-(4-Fluorophenyl)acetic acid (385.3 $\mathrm{mg}, 2.5 \mathrm{mmol}, 1$ equiv), thiophenol (303.0 mg, $2.75 \mathrm{mmol}, 1.1$ equiv), DCC (515.8 mg, $2.5 \mathrm{mmol}, 1$ equiv), and anhydrous THF ( $5 \mathrm{~mL}$ ) were used. After workup, the product was purified by flash chromatography on silica gel with hexaneEtOAc (96:4) as eluent; yield: $603.4 \mathrm{mg}(98 \%)$; white solid; $\mathrm{mp} 35^{\circ} \mathrm{C}$; $R_{f}=0.35$ (hexane-EtOAc, 9:1).

${ }^{1} \mathrm{H}$ NMR (300 MHz, CDCl $)$ : $\delta=7.39(\mathrm{~s}, 5 \mathrm{H}), 7.28(\mathrm{t}, J=9.0 \mathrm{~Hz}, 2 \mathrm{H})$, $7.06(\mathrm{t}, J=9.0 \mathrm{~Hz}, 2 \mathrm{H}), 3.89(\mathrm{~s}, 2 \mathrm{H})$.

${ }^{13} \mathrm{C}$ NMR $\left(75 \mathrm{MHz}, \mathrm{CDCl}_{3}\right): \delta=195.2,162.4(\mathrm{~d}, J=246.3 \mathrm{~Hz}), 134.5$, 131.4, 131.3, 129.6, 129.3, 129.2, 127.7, 115.8, 115.5, 49.6.

${ }^{19} \mathrm{~F}$ NMR $\left(282 \mathrm{MHz}, \mathrm{CDCl}_{3}\right): \delta=-115.35$.

MS (ESI+): $m / z=247.2[\mathrm{M}+\mathrm{H}]^{+}$.

\section{S-Phenyl 2-(4-Isobutylphenyl)ethanethioate (9b)}

2-(4-Isobutylphenyl)acetic acid (480.6 mg, $2.5 \mathrm{mmol}, 1$ equiv), thiophenol (303.0 mg, $2.75 \mathrm{mmol}, 1.1$ equiv), DCC (515.8 mg, $2.5 \mathrm{mmol}, 1$ equiv), and anhydrous THF ( $5 \mathrm{~mL}$ ) were used. After workup, the product was purified by flash chromatography on silica gel with hexaneEtOAc (98:2) as eluent; yield: $604.4 \mathrm{mg}$ (85\%); pale-yellow solid; mp $30{ }^{\circ} \mathrm{C} ; R_{f}=0.51$ (hexane-EtOAc, $9: 1$ ).

${ }^{1} \mathrm{H} \mathrm{NMR}\left(300 \mathrm{MHz}, \mathrm{CDCl}_{3}\right): \delta=7.30-7.38(\mathrm{~m}, 5 \mathrm{H}), 7.24(\mathrm{~d}, J=7.9 \mathrm{~Hz}, 2$ H), $7.13(\mathrm{~d}, J=7.9 \mathrm{~Hz}, 2 \mathrm{H}), 3.89(\mathrm{~s}, 2 \mathrm{H}), 2.48(\mathrm{~d}, J=7.2 \mathrm{~Hz}, 2 \mathrm{H}), 1.94-$ $1.80(\mathrm{~m}, 1 \mathrm{H}), 0.91(\mathrm{~d}, J=6.6 \mathrm{~Hz}, 6 \mathrm{H})$.

${ }^{13} \mathrm{C} \mathrm{NMR}\left(75 \mathrm{MHz}, \mathrm{CDCl}_{3}\right): \delta=195.6,141.1,134.5,130.6,129.4,129.5$, $129.4,129.2,128.0,49.8,45.2,30.3,22.5$.

MS (ESI+): $m / z=285.2[\mathrm{M}+\mathrm{H}]^{+}$and $307.0[\mathrm{M}+\mathrm{Na}]^{+}$.

Enantioselective Direct Aldol Reaction between Thioesters and Aldehydes; General Procedure

To a stirred solution of catalyst $\mathbf{1}$ or $\mathbf{2}$ (0.1 equiv) in $\mathrm{CH}_{2} \mathrm{Cl}_{2}(2 \mathrm{~mL})$ were added the thioester $\left(0.6 \mathrm{mmol}, 2\right.$ equiv) and $i-\mathrm{Pr}_{2} \mathrm{NEt}(6 \mathrm{mmol}$, 10 equiv). The mixture was then cooled to $0{ }^{\circ} \mathrm{C}$ and freshly distilled 
$\mathrm{SiCl}_{4}$ (0.9 mmol, 3 equiv) was added dropwise via syringe. After 15 min, freshly purified aldehyde $(0.3 \mathrm{mmol}, 1$ equiv $)$ was added. The mixture was stirred for $24 \mathrm{~h}$, then quenched by the addition of sat. aq $\mathrm{NaHCO}_{3}(3 \mathrm{~mL})$. The mixture was allowed to warm up to r.t., stirred for $30 \mathrm{~min}$, and partitioned between $\mathrm{H}_{2} \mathrm{O}(5 \mathrm{~mL})$ and EtOAc $(15 \mathrm{~mL})$. The organic layer was separated and the aqueous layer was extracted with EtOAc $(15 \mathrm{~mL})$. The combined organic layers were washed with sat. aq $\mathrm{NH}_{4} \mathrm{Cl}(10 \mathrm{~mL})$ and brine $(10 \mathrm{~mL})$, dried $\left(\mathrm{Na}_{2} \mathrm{SO}_{4}\right)$, filtered, and concentrated under vacuum at r.t. The crude product was purified by column chromatography with 9:1 hexane-EtOAc mixture as eluent (see below) to afford the pure aldol adducts. Yields and ee for each reaction are indicated in Tables 1-3. The syn/anti ratio was determined by ${ }^{1} \mathrm{H}$ NMR spectroscopy of the crude product; the enantiomeric excess was determined by HPLC on a chiral stationary phase.

\section{S-(Pyridin-2-yl) 3-Hydroxy-2,3-diphenylpropanethioate (7a)}

Thioester 4 (137 mg, $0.6 \mathrm{mmol}, 2$ equiv), catalyst 2 (19 mg, 0.03 mmol, 0.1 equiv), benzaldehyde ( $32 \mathrm{mg}, 0.3 \mathrm{mmol}, 1$ equiv), $i-\mathrm{Pr}_{2} \mathrm{NEt}$ ( $775 \mathrm{mg}, 6 \mathrm{mmol}, 10$ equiv), $\mathrm{SiCl}_{4}$ (153 mg, $0.9 \mathrm{mmol}, 3$ equiv), and anhydrous $\mathrm{CH}_{2} \mathrm{Cl}_{2}(2 \mathrm{~mL})$ were used. After workup, the product was purified by flash chromatography on silica gel with hexane-EtOAc (7:3) as eluent. This purification furnished only one diastereoisomer; yield: $14.1 \mathrm{mg}(14 \%)$; yellow solid; $\mathrm{mp} 38-40{ }^{\circ} \mathrm{C} ; R_{f}=0.48$ (hexaneEtOAc, 6:4, stained with phosphomolybdic acid).

HPLC: Chiralcel OD-H; eluent: hexane- $i$-PrOH (85:15); flux: 0.8 $\mathrm{mL} / \mathrm{min}$; detection: $230 \mathrm{~nm} ; t_{\mathrm{R}}=24.0 \mathrm{~min}, t_{\mathrm{R}}=30.6 \mathrm{~min}$.

${ }^{1} \mathrm{H} \mathrm{NMR}$ (300 MHz, $\mathrm{CDCl}_{3}$ ): $\delta=8.59(\mathrm{~d}, J=4.4 \mathrm{~Hz}, 1 \mathrm{H}) 7.72(\mathrm{t}, J=7.7$ $\mathrm{Hz}, 1 \mathrm{H}), 7.60(\mathrm{~d}, J=7.7 \mathrm{~Hz}, 1 \mathrm{H}), 7.35-7.08(\mathrm{~m}, 11 \mathrm{H}), 5.31(\mathrm{~d}, J=9.3$ $\mathrm{Hz}, 1 \mathrm{H}), 4.20(\mathrm{~d}, J=9.3 \mathrm{~Hz}, 1 \mathrm{H})$.

${ }^{13} \mathrm{C}$ NMR $\left(75 \mathrm{MHz}, \mathrm{CDCl}_{3}\right): \delta=197.9,151.2,150.3,140.5,137.5,137.3$, 134.2, 130.1, 129.0, 128.7, 128.1, 127.9, 126.6, 123.7, 77.2, 68.4.

MS (ESI+): $m / z=358.2[\mathrm{M}+\mathrm{Na}]^{+}$.

\section{S-(Pyridin-2-yl) 3-(4-Chlorophenyl)-3-hydroxy-2-phenylpropan- ethioate (7b)}

Thioester 4 (137 mg, $0.6 \mathrm{mmol}, 2$ equiv), catalyst 2 (19 mg, 0.03 mmol, 0.1 equiv), 4-chlorobenzaldehyde ( $42 \mathrm{mg}, 0.3 \mathrm{mmol}, 1$ equiv), $i-\mathrm{Pr}_{2} \mathrm{NEt}$ (775 mg, $6 \mathrm{mmol}, 10$ equiv), $\mathrm{SiCl}_{4}(153 \mathrm{mg}, 0.9 \mathrm{mmol}, 3$ equiv), and anhydrous $\mathrm{CH}_{2} \mathrm{Cl}_{2}(2 \mathrm{~mL})$ were used. After workup, the product was purified by flash chromatography on silica gel with hexane-EtOAc (7:3) as eluent. This purification furnished a mixture of syn- and anti-diastereoisomers; yield: $16.7 \mathrm{mg}$ (15\%); pale-yellow solid; $\mathrm{mp} 40-43^{\circ} \mathrm{C} ; R_{f}=0.21$ (hexane-EtOAc, $6: 4$, stained with phosphomolybdic acid).

HPLC: The two diastereoisomers were separated on Supelco Ascentis Si column $(3 \mathrm{u})$ with hexane- $i$-PrOH $(95: 5)\left(t_{\mathrm{R}}=8.87 \mathrm{~min}\right.$, for minor diasteroisomer, $t_{\mathrm{R}}=9.07 \mathrm{~min}$, for major diastereoisomer). The enantiomeric excess of each separated diastereoisomer was determined on Chiralpak AD column; eluent: hexane- $i$-PrOH (7:3); flux: $0.8 \mathrm{~mL} / \mathrm{min}$; detection: $220 \mathrm{~nm} ; t_{\mathrm{R}}=13.3 \mathrm{~min}, t_{\mathrm{R}}=18.2 \mathrm{~min}$.

${ }^{1} \mathrm{H}$ NMR (300 MHz, $\mathrm{CDCl}_{3}$ ): $\delta=8.59$ (d, $J=4.4 \mathrm{~Hz}, 1 \mathrm{H}$, major), 8.45 (d, $J=3.1 \mathrm{~Hz}, 1 \mathrm{H}$, minor), $7.70(\mathrm{t}, J=7.7 \mathrm{~Hz}, 1 \mathrm{H}$, minor), 7.59 (t, $J=6.8$ $\mathrm{Hz}, 1 \mathrm{H}$, major), 7.31-6.94 (m, $11 \mathrm{H}), 5.29$ (d, $J=6.3 \mathrm{~Hz}, 1 \mathrm{H}$, major), $5.28(\mathrm{~d}, J=3.1 \mathrm{~Hz}, 1 \mathrm{H}$, minor), $4.13(\mathrm{~d}, J=5.2 \mathrm{~Hz}, 1 \mathrm{H}$, minor), 4.10 (d, $J=3.0 \mathrm{~Hz}, 1 \mathrm{H}$, major).

${ }^{13} \mathrm{C}$ NMR $\left(75 \mathrm{MHz}, \mathrm{CDCl}_{3}\right): \delta=197.9,150.3,149.5,139.0,137.5,133.9$, 133.6, 130.2, 129.0, 128.9, 128.7, 128.3, 128.6, 128.0, 123.8, 121.2, $119.8,76.0,68.3$.

MS (ESI+): $m / z=392.1[\mathrm{M}+\mathrm{Na}]^{+}$.

\section{S-Phenyl 3-Hydroxy-2,3-diphenylpropanethioate (8a)}

Thioester 5 (137 mg, $0.6 \mathrm{mmol}, 2$ equiv), catalyst 1 (18 mg, 0.03 mmol, 0.1 equiv), benzaldehyde ( $32 \mathrm{mg}, 0.3 \mathrm{mmol}, 1$ equiv), $i-\mathrm{Pr}_{2} \mathrm{NEt}$ ( $775 \mathrm{mg}, 6 \mathrm{mmol}, 10$ equiv), $\mathrm{SiCl}_{4}$ (153 $\mathrm{mg}, 0.9 \mathrm{mmol}, 3$ equiv), and anhydrous $\mathrm{CH}_{2} \mathrm{Cl}_{2}(2 \mathrm{~mL})$ were used. After workup, the product was purified by flash chromatography on silica gel with hexane-EtOAc (9:1) as eluent. This purification furnished a mixture of syn- and antidiastereoisomers; yield: $70.2 \mathrm{mg}$ (70\%); white solid; mp 107-109 ${ }^{\circ} \mathrm{C}$; $R_{f}=0.14$ (hexane-EtOAc, 9:1, stained with phosphomolybdic acid).

HPLC: Chiralcel OD-H; eluent: hexane- $i-\mathrm{PrOH}$ (93:7); flux: 0.8 $\mathrm{mL} / \mathrm{min}$; detection: $230 \mathrm{~nm}$; $(2 S, 3 R)$-anti-enantiomer, $t_{\mathrm{R}}=19.7 \mathrm{~min}$; (2S,3S)-syn-enantiomer, $t_{\mathrm{R}}=22.8 \mathrm{~min}$; $(2 R, 3 S)$-anti-enantiomer, $t_{\mathrm{R}}=$ $27.1 \mathrm{~min} ;(2 R, 3 R)$-syn-enantiomer, $t_{\mathrm{R}}=29.8 \mathrm{~min}$.

${ }^{1} \mathrm{H} \mathrm{NMR}\left(300 \mathrm{MHz}, \mathrm{CDCl}_{3}\right): \delta=7.44-7.08(\mathrm{~m}, 15 \mathrm{H}), 5.38(\mathrm{~d}, J=8.0 \mathrm{~Hz}$, $1 \mathrm{H}$, syn), 5.31 (d, $J=9.0 \mathrm{~Hz}, 1 \mathrm{H}$, anti), 4.21 (d, $J=9.0 \mathrm{~Hz}, 1 \mathrm{H}$, anti), 4.16 (d, J = 8.0 Hz, $1 \mathrm{H}$, syn), 3.00 (br, $1 \mathrm{H}$, syn) 2.48 (br, $1 \mathrm{H}$, syn).

${ }^{13} \mathrm{C}$ NMR (75 MHz, $\mathrm{CDCl}_{3}$ ): $\delta=199.1$ (anti), 197.7 (syn), 140.6, 140.5, $134.5,134.4,134.3,134.2,129.6,129.4,129.2,129.1,128.9,128.8$, $128.7,128.3,128.1,127.9,126.8,126.6,75.4,67.7$.

MS (ESI+): $m / z=357.2[\mathrm{M}+\mathrm{Na}]^{+}$.

\section{S-Phenyl 3-Hydroxy-3-(4-methoxyphenyl)-2-phenylpropanethio- ate (8b)}

Thioester 5 (137 mg, $0.6 \mathrm{mmol}, 2$ equiv), catalyst 2 (19 mg, 0.03 mmol, 0.1 equiv), 4-methoxybenzaldehyde $(41 \mathrm{mg}, 0.3 \mathrm{mmol}, 1$ equiv), $i-\mathrm{Pr}_{2} \mathrm{NEt}$ ( $775 \mathrm{mg}, 6 \mathrm{mmol}, 10$ equiv), $\mathrm{SiCl}_{4}(153 \mathrm{mg}, 0.9 \mathrm{mmol}$, 3 equiv), and anhydrous $\mathrm{CH}_{2} \mathrm{Cl}_{2}(2 \mathrm{~mL})$ were used. After workup, the product was purified by flash chromatography on silica gel with hexane-EtOAc (9:1) as eluent. This purification furnished a mixture of syn- and anti-diastereoisomers; yield: $75.5 \mathrm{mg}$ (69\%); white solid, $\mathrm{mp}$ $36-39{ }^{\circ} \mathrm{C} ; R_{f}=0.07$ (hexane-EtOAc, $9: 1$, stained with phosphomolybdic acid).

HPLC: Chiralcel AS-3; eluent: hexane- $i-\operatorname{PrOH}(8: 2)$; flux: $0.8 \mathrm{~mL} / \mathrm{min}$; detection: $230 \mathrm{~nm}$; anti-enantiomer, $t_{\mathrm{R}}=12.8 \mathrm{~min}$; syn-enantiomer, $t_{\mathrm{R}}=14.9 \mathrm{~min}$; anti-enantiomer, $t_{\mathrm{R}}=17.8 \mathrm{~min}$; syn-enantiomer, $t_{\mathrm{R}}=$ 30.9 min.

${ }^{1} \mathrm{H} \mathrm{NMR}\left(300 \mathrm{MHz}, \mathrm{CDCl}_{3}\right): \delta=7.34-7.11(\mathrm{~m}, 10 \mathrm{H}), 7.26(\mathrm{~d}, J=7.5 \mathrm{~Hz}$, $2 \mathrm{H}, s y n), 7.15$ (d, $J=7.5 \mathrm{~Hz}, 2 \mathrm{H}$, anti), 6.87 (d, $J=7.5 \mathrm{~Hz}, 2 \mathrm{H}, s y n$ ), $6.71(\mathrm{~d}, J=7.5 \mathrm{~Hz}, 2 \mathrm{H}$, anti), $5.29(\mathrm{~d}, J=8.0 \mathrm{~Hz}, 1 \mathrm{H}$, syn), 5.23 (d, $J=8.0 \mathrm{~Hz}, 1 \mathrm{H}$, anti), $4.15(\mathrm{~d}, J=9.0 \mathrm{~Hz}, 1 \mathrm{H}$, anti), $4.12(\mathrm{~d}, J=9.0 \mathrm{~Hz}, 1$ $\mathrm{H}$, syn), 3.81 (s, $3 \mathrm{H}$, syn), 3.73 (s, $3 \mathrm{H}$, anti).

${ }^{13} \mathrm{C}$ NMR $\left(75 \mathrm{MHz}, \mathrm{CDCl}_{3}\right): \delta=197.6,159.4,134.5,134.4,132.7,129.6$, $129.4,129.2$, 128.8, 128.7, 128.3, 128.1, 127.8, 127.2, 113.7, 113.5, 75.1, 67.8, 55.3.

MS (ESI+): $m / z=387.2[\mathrm{M}+\mathrm{Na}]^{+}$.

\section{S-Phenyl 3-Hydroxy-3-(4-chlorophenyl)-2-phenylpropanethioate (8c)}

Thioester 5 (137 mg, $0.6 \mathrm{mmol}, 2$ equiv), catalyst 1 (18 mg, 0.03 mmol, 0.1 equiv), 4-chlorobenzaldehyde ( $42 \mathrm{mg}, 0.3 \mathrm{mmol}, 1$ equiv), $i$ - $\mathrm{Pr}_{2} \mathrm{NEt}$ (775 mg, $6 \mathrm{mmol}, 10$ equiv), $\mathrm{SiCl}_{4}(153 \mathrm{mg}, 0.9 \mathrm{mmol}, 3$ equiv), and anhydrous $\mathrm{CH}_{2} \mathrm{Cl}_{2}(2 \mathrm{~mL})$ were used. After workup, the product was purified by flash chromatography on silica gel with hexane-EtOAc (9:1) as eluent. This purification furnished a mixture of syn- and anti-diastereoisomers; yield: $73.1 \mathrm{mg}$ (66\%); white solid; mp $134-136{ }^{\circ} \mathrm{C} ; R_{f}=0.10$ (hexane-EtOAc, 9:1, stained with phosphomolybdic acid). 
HPLC: Chiralcel AS-3; eluent: hexane-i-PrOH (8:2); flux: $0.8 \mathrm{~mL} / \mathrm{min}$; detection: $230 \mathrm{~nm}$; anti-enantiomer, $t_{\mathrm{R}}=9.1 \mathrm{~min}$; anti-enantiomer, $t_{\mathrm{R}}=9.8 \mathrm{~min}$; syn-enantiomer, $t_{\mathrm{R}}=10.4 \mathrm{~min}$; syn-enantiomer, $t_{\mathrm{R}}=16.4$ min.

${ }^{1} \mathrm{H}$ NMR $\left(300 \mathrm{MHz}, \mathrm{CDCl}_{3}\right): \delta=7.39-6.99(\mathrm{~m}, 14 \mathrm{H}), 5.36(\mathrm{~d}, J=7.0 \mathrm{~Hz}$, $1 \mathrm{H}$, syn), 5.27 (d, J=9.1 Hz, $1 \mathrm{H}$, anti), $4.12(\mathrm{~d}, J=9.0 \mathrm{~Hz}, 1 \mathrm{H}$, anti), 4.10 (d, $J=7.0 \mathrm{~Hz}, 1 \mathrm{H}, \mathrm{syn}), 3.07$ (d, J=3.8 Hz, $1 \mathrm{H}$, anti), 2.57 (d, $J=2.3 \mathrm{~Hz}, 1 \mathrm{H}$, syn).

${ }^{13} \mathrm{C}$ NMR (75 MHz, $\mathrm{CDCl}_{3}$ ): $\delta=199.1$ (anti), 197.8 (syn), 139.2, 134.5, 134.4, 133.6, 129.7, 129.5, 129.3, 128.9, 128.8, 128.5, 128.3, 128.1, 128.0, 127.3, 76.1 (anti), 74.6 (syn), 67.7 (anti), 67.4 (syn).

MS (ESI+): $m / z=391.1[\mathrm{M}+\mathrm{Na}]^{+}$.

\section{S-Phenyl 3-Hydroxy-2-phenyl-3-(2-methylphenyl)propanethioate (8d)}

Thioester 5 ( $91 \mathrm{mg}, 0.4 \mathrm{mmol}, 2$ equiv), catalyst 2 ( $12 \mathrm{mg}, 0.02 \mathrm{mmol}$, 0.1 equiv), 2-methylbenzaldehyde ( $24 \mathrm{mg}, 0.2 \mathrm{mmol}, 1$ equiv), $i$ $\mathrm{Pr}_{2} \mathrm{NEt}$ (517 mg, $4 \mathrm{mmol}, 10$ equiv), $\mathrm{SiCl}_{4}$ (102 mg, $0.6 \mathrm{mmol}, 3$ equiv), and anhydrous $\mathrm{CH}_{2} \mathrm{Cl}_{2}(1.3 \mathrm{~mL})$ were used. After workup, the product was purified by flash chromatography on silica gel with hexane-EtOAc (9:1) as eluent. This purification furnished a mixture of syn- and anti-diastereoisomers; yield: $24.7 \mathrm{mg}$ (35\%); pale-yellow solid; mp $30-32{ }^{\circ} \mathrm{C} ; R_{f}=0.14$ (hexane-EtOAc, $9: 1$, stained with phosphomolybdic acid).

HPLC: Chiralcel OD-H; eluent: hexane-i-PrOH (9:1); flux: 0.8 $\mathrm{mL} / \mathrm{min}$; detection: $254 \mathrm{~nm}$; syn-enantiomer, $t_{\mathrm{R}}=10.6 \mathrm{~min}$; anti-enantiomer, $t_{\mathrm{R}}=12.3$; syn-enantiomer; $t_{\mathrm{R}}=13.4 \mathrm{~min}$; anti-enantiomer, $t_{\mathrm{R}}=14.4 \mathrm{~min}$.

${ }^{1} \mathrm{H} \mathrm{NMR}\left(300 \mathrm{MHz}, \mathrm{CDCl}_{3}\right): \delta=7.45-7.31(\mathrm{~m}, 8 \mathrm{H}), 7.31-7.00(\mathrm{~m}, 7 \mathrm{H})$, $5.62(\mathrm{~d}, J=6.8 \mathrm{~Hz}, 1 \mathrm{H}$, anti), 5.55 (d, $J=8.8 \mathrm{~Hz}, 1 \mathrm{H}$, syn), 4.32 (d, $J=8.8 \mathrm{~Hz}, 1 \mathrm{H}$, syn), 4.26 (d, J=6.8 Hz, $2 \mathrm{H}$, anti), 2.47 (s, $3 \mathrm{H})$.

${ }^{13} \mathrm{C}$ NMR $\left(75 \mathrm{MHz}, \mathrm{CDCl}_{3}\right): \delta=197.7,138.4,135.0,134.3,130.4,129.6$, 129.1, 128.7, 128.2, 127.9, 127.2, 126.9, 126.1, 71.6, 65.9, 19.4.

MS (ESI+): $m / z=371.1[\mathrm{M}+\mathrm{Na}]^{+}$.

\section{S-Phenyl 3-Hydroxy-2-phenyl-3-(3-methylphenyl)propanethioate} (8e)

Thioester 5 ( $91 \mathrm{mg}, 0.4 \mathrm{mmol}, 2$ equiv), catalyst 2 (12 mg, $0.02 \mathrm{mmol}$, 0.1 equiv), 3-methylbenzaldehyde ( $24 \mathrm{mg}, 0.2 \mathrm{mmol}, 1$ equiv), $i$ $\mathrm{Pr}_{2} \mathrm{NEt}$ (517 mg, 4 mmol, 10 equiv), $\mathrm{SiCl}_{4}$ (102 mg, $0.6 \mathrm{mmol}, 3$ equiv), and anhydrous $\mathrm{CH}_{2} \mathrm{Cl}_{2}(1.3 \mathrm{~mL})$ were used. After workup, the product was purified by flash chromatography on silica gel with hexaneEtOAc (9:1) as eluent. This purification furnished a mixture of synand anti-diastereoisomers; yield: $56.0 \mathrm{mg}$ (80\%); pale-yellow solid; $\mathrm{mp} 33-35^{\circ} \mathrm{C} ; R_{f}=0.13$ (hexane-EtOAc, 9:1, stained with phosphomolybdic acid).

HPLC: Phenomenex Lux-3u cellulose-2; eluent: hexane- $i$-PrOH (95:5); flux: $0.8 \mathrm{~mL} / \mathrm{min}$; detection: $210 \mathrm{~nm}$; syn-enantiomer, $t_{\mathrm{R}}=3.7$ min; syn-enantiomer, $t_{\mathrm{R}}=5.5 \mathrm{~min}$; anti-enantiomer, $t_{\mathrm{R}}=7.1 \mathrm{~min}$; anti-enantiomer, $t_{\mathrm{R}}=8.5 \mathrm{~min}$.

${ }^{1} \mathrm{H} \mathrm{NMR}\left(300 \mathrm{MHz}, \mathrm{CDCl}_{3}\right): \delta=7.50-6.88(\mathrm{~m}, 15 \mathrm{H}, \mathrm{syn}+$ anti) $5.34(\mathrm{~d}$, $J=7.6 \mathrm{~Hz}, 1 \mathrm{H}$, syn), 5.26 (d, $J=9.0 \mathrm{~Hz}, 1 \mathrm{H}$, anti), 4.21 (d, $J=9.0 \mathrm{~Hz}, 1$ H, syn), 4.16 (d, J = 7.6 Hz, $1 \mathrm{H}$, anti), 2.38 (s, $3 \mathrm{H}$, syn), $2.27(\mathrm{~s}, 3 \mathrm{H}$, anti).

${ }^{13} \mathrm{C}$ NMR (75 MHz, $\mathrm{CDCl}_{3}$ ): $\delta=199.0$ (anti), 197.5 (syn), 140.5, 140.4, 137.9, 137.7, 134.5, 134.4, 134.2, 129.5, 129.4, 129.2, 129.1, 128.9, 128.8, 128.6, 128.2, 127.9, 127.8, 127.5, 127.2, 123.9, 123.7, 75.5, 67.7, 21.4 .
MS (ESI+): $m / z=371.1[\mathrm{M}+\mathrm{Na}]^{+}$.

\section{S-Phenyl 3-Hydroxy-3-(mesityl)-2-phenylpropanethioate (8f)}

Thioester 5 ( $91 \mathrm{mg}, 0.4 \mathrm{mmol}, 2$ equiv), catalyst 2 (12 mg, $0.02 \mathrm{mmol}$, 0.1 equiv), mesitaldehyde ( $30 \mathrm{mg}, 0.2 \mathrm{mmol}, 1$ equiv), $i$ - $\operatorname{Pr}_{2} \mathrm{NEt}$ (517 $\mathrm{mg}, 4 \mathrm{mmol}, 10$ equiv), $\mathrm{SiCl}_{4}$ (102 mg, $0.6 \mathrm{mmol}, 3$ equiv), and anhydrous $\mathrm{CH}_{2} \mathrm{Cl}_{2}(1.3 \mathrm{~mL})$ were used. After workup, the product was purified by flash chromatography on silica gel with hexane-EtOAc (9:1) as eluent. This purification furnished only the syn-diastereoisomer; yield: $44.0 \mathrm{mg}$ (58\%); pale-yellow solid; $\mathrm{mp} 57-60{ }^{\circ} \mathrm{C} ; R_{f}=0.16$ (hexane-EtOAc, 9:1, stained with phosphomolybdic acid).

HPLC: Phenomenex Lux-3u cellulose-1 equipped with security guard filter; eluent: hexane- $i$-PrOH (95:5); flux: $0.8 \mathrm{~mL} / \mathrm{min}$; detection: $210 \mathrm{~nm}$; syn-minor enantiomer, $t_{\mathrm{R}}=4.51 \mathrm{~min}$; syn-major enantiomer, $t_{\mathrm{R}}=06.1 \mathrm{~min}$.

${ }^{1} \mathrm{H}$ NMR $\left(300 \mathrm{MHz}, \mathrm{CDCl}_{3}\right): \delta=7.59(\mathrm{~d}, J=7.1 \mathrm{~Hz}, 2 \mathrm{H}), 7.50-7.21(\mathrm{~m}, 6$ H), $7.04(\mathrm{~d}, J=6.9 \mathrm{~Hz}, 2 \mathrm{H}), 6.92(\mathrm{~s}, 2 \mathrm{H}), 5.72(\mathrm{~d}, J=9.3 \mathrm{~Hz}, 1 \mathrm{H}), 4.68$ (d, $J=9.4 \mathrm{~Hz}, 1 \mathrm{H}), 2.55$ (s, $6 \mathrm{H}), 2.33(\mathrm{~s}, 3 \mathrm{H}), 1.88(\mathrm{br}, 1 \mathrm{H})$.

${ }^{13} \mathrm{C} \mathrm{NMR}\left(75 \mathrm{MHz}, \mathrm{CDCl}_{3}\right): \delta=196.3,137.5,137.1,135.6,134.3,132.8$, 130.3, 129.4, 129.1, 129.0, 128.2, 127.4, 73.0, 64.5, 20.9 .

MS (ESI+): $m / z=399.1[\mathrm{M}+\mathrm{Na}]^{+}$.

\section{S-Phenyl 3-(2,6-Dimethoxyphenyl)-3-hydroxy-2-phenylpropane- thioate $(8 \mathrm{~g})$}

Thioester 5 ( $91 \mathrm{mg}, 0.4 \mathrm{mmol}, 2$ equiv), catalyst 2 (12 mg, $0.02 \mathrm{mmol}$, 0.1 equiv), 2,6-dimethoxybenzaldehyde ( $33 \mathrm{mg}, 0.2 \mathrm{mmol}, 1$ equiv), $i$ $\mathrm{Pr}_{2} \mathrm{NEt}$ (517 mg, $4 \mathrm{mmol}, 10$ equiv), $\mathrm{SiCl}_{4}$ ( $102 \mathrm{mg}, 0.6 \mathrm{mmol}, 3$ equiv), and anhydrous $\mathrm{CH}_{2} \mathrm{Cl}_{2}(1.3 \mathrm{~mL})$ were used. After workup, the product was purified by flash chromatography on silica gel with hexaneEtOAc (9:1) as eluent. This purification furnished a mixture of synand anti-diastereoisomers; yield: $48.4 \mathrm{mg}$ (61\%); pale-yellow solid; $\mathrm{mp} 77-80^{\circ} \mathrm{C} ; R_{f}=0.10$ (hexane-EtOAc, 9:1, stained with phosphomolybdic acid).

HPLC: Phenomenex Lux-3u cellulose-2; eluent: hexane-EtOH (65:35); flux: $0.8 \mathrm{~mL} / \mathrm{min}$; detection: $230 \mathrm{~nm}$; syn-enantiomer, $t_{\mathrm{R}}=$ $8.3 \mathrm{~min}$; syn-enantiomer, $t_{\mathrm{R}}=10.1 \mathrm{~min}$; anti-enantiomer, $t_{\mathrm{R}}=10.6$ min; anti-enantiomer, $t_{\mathrm{R}}=11.1 \mathrm{~min}$.

${ }^{1} \mathrm{H}$ NMR $\left(300 \mathrm{MHz}, \mathrm{CDCl}_{3}\right): \delta=7.52(\mathrm{~d}, J=7.7 \mathrm{~Hz}, 2 \mathrm{H}), 7.45-7.19(\mathrm{~m}, 7$ $\mathrm{H}), 7.10(\mathrm{~d}, J=7.4 \mathrm{~Hz}, 2 \mathrm{H}), 6.62(\mathrm{dd}, J=8.4,2.6 \mathrm{~Hz}, 1 \mathrm{H}), 5.90$ (d, $J=7.9$ $\mathrm{Hz}, 1 \mathrm{H}), 4.56(\mathrm{~d}, J=8.2 \mathrm{~Hz}, 1 \mathrm{H}), 3.83(\mathrm{~d}, J=2.4 \mathrm{~Hz}, 1 \mathrm{H}), 2.07$ (d, $J=2.3 \mathrm{~Hz}, 1 \mathrm{H})$.

${ }^{13} \mathrm{C}$ NMR (75 MHz, $\mathrm{CDCl}_{3}$ ): $\delta=195.2,158.2,136.0,134.4,129.6,129.4$, 129.1, 128.9, 128.4, 127.6, 116.8, 104.4, 103.9, 69.3, 65.5, 55.9.

MS (ESI+): $m / z=417.1[\mathrm{M}+\mathrm{Na}]^{+}$.

\section{S-Phenyl 3-Hydroxy-3-(4-fluorophenyl)-2-phenylpropanethioate} (8h)

Thioester 5 (91 mg, $0.4 \mathrm{mmol}, 2$ equiv), catalyst $2(12 \mathrm{mg}, 0.02 \mathrm{mmol}$, 0.1 equiv), 4-fluorobenzaldehyde ( $25 \mathrm{mg}, 0.2 \mathrm{mmol}, 1$ equiv), $i-\mathrm{Pr}_{2} \mathrm{NEt}$ (517 mg, $4 \mathrm{mmol}, 10$ equiv), $\mathrm{SiCl}_{4}$ (102 $\mathrm{mg}, 0.6 \mathrm{mmol}, 3$ equiv), and anhydrous $\mathrm{CH}_{2} \mathrm{Cl}_{2}(1.3 \mathrm{~mL})$ were used. After workup, the product was purified by flash chromatography on silica gel with hexane-EtOAc (9:1) as eluent. This purification furnished a mixture of syn- and antidiastereoisomers; yield: $41.5 \mathrm{mg}$ (59\%); white solid; mp 92-95 ${ }^{\circ} \mathrm{C}$; $R_{f}=0.11$ (hexane-EtOAc, 9:1, stained with phosphomolybdic acid).

HPLC: Chiralcel OD-H; eluent: hexane- $i-\operatorname{PrOH}$ (9:1); flux: 0.8 $\mathrm{mL} / \mathrm{min}$; detection: $210 \mathrm{~nm}$; anti-enantiomer, $t_{\mathrm{R}}=14.0 \mathrm{~min}$; syn-enantiomer, $t_{\mathrm{R}}=16.5 \mathrm{~min}$; anti-enantiomer, $t_{\mathrm{R}}=17.9 \mathrm{~min}$; syn-enantiomer, $t_{\mathrm{R}}=21.3 \mathrm{~min}$. 
${ }^{1} \mathrm{H}$ NMR $\left(300 \mathrm{MHz}, \mathrm{CDCl}_{3}\right): \delta=7.48-7.15(\mathrm{~m}, 10 \mathrm{H}), 7.15-7.03(\mathrm{~m}, 2$ $\mathrm{H}), 6.89(\mathrm{t}, J=8.6 \mathrm{~Hz}, 1 \mathrm{H}), 5.37$ (d, J= 7.3 Hz, $1 \mathrm{H}$, syn), 5.29 (d, $J=9.2$ $\mathrm{Hz}, 1 \mathrm{H}$, anti), $4.15(\mathrm{~d}, J=9.2 \mathrm{~Hz}, 1 \mathrm{H}$, anti), $4.11(\mathrm{~d}, J=7.3 \mathrm{~Hz}, 1 \mathrm{H}$, syn), 3.01 (br, $1 \mathrm{H}$, anti), 2.52 (br, $1 \mathrm{H}$, syn).

${ }^{13} \mathrm{C}$ NMR (75 MHz, $\mathrm{CDCl}_{3}$ ): $\delta$ = 199.1 (anti), 197.7 (syn), 162.7 (d, $J=228 \mathrm{~Hz}$ ), 136.5, 136.3, 134.5, 134.4, 133.9, 129.7, 129.4, 129.2, $128.9,128.8,128.6,128.5,128.4,128.3,128.2,128.0,127.0,115.3$, $115.1,115.0,114.8,76.1,74.7,67.9,67.7$.

${ }^{19} \mathrm{~F}$ NMR (282 MHz, $\mathrm{CDCl}_{3}$ ): $\delta=-114.5$ (syn), -114.7 (anti).

MS (ESI+): $m / z=375.0[\mathrm{M}+\mathrm{Na}]^{+}$.

\section{S-Phenyl 3-Hydroxy-2-phenyl-3-[4-(trifluoromethyl)phenyl]pro- panethioate $(8 \mathrm{i})$}

Thioester 5 ( $91 \mathrm{mg}, 0.4 \mathrm{mmol}, 2$ equiv), catalyst 2 (12 mg, $0.02 \mathrm{mmol}$, 0.1 equiv), 4-(trifluoromethyl)benzaldehyde (35 mg, $0.2 \mathrm{mmol}, 1$ equiv), $i-\mathrm{Pr}_{2} \mathrm{NEt}$ ( $517 \mathrm{mg}, 4 \mathrm{mmol}, 10$ equiv), $\mathrm{SiCl}_{4}$ (102 mg, $0.6 \mathrm{mmol}$, 3 equiv), and anhydrous $\mathrm{CH}_{2} \mathrm{Cl}_{2}(1.3 \mathrm{~mL}$ ) were used. After workup, the product was purified by flash chromatography on silica gel with hexane-EtOAc (9:1) as eluent. This purification furnished a mixture of syn- and anti-diastereoisomers; yield: $60.9 \mathrm{mg}$ (76\%); white solid; mp $110-112{ }^{\circ} \mathrm{C} ; R_{f}=0.11$ (hexane-EtOAc, 9:1, stained with phosphomolybdic acid).

HPLC: Phenomenex Lux-3u cellulose-1 equipped with securityguard filter; eluent: hexane- $i$-PrOH (95:5); flux: $0.8 \mathrm{~mL} / \mathrm{min}$; detection: $210 \mathrm{~nm}$; anti-enantiomer, $t_{\mathrm{R}}=9.4 \mathrm{~min}$; anti-enantiomer, $t_{\mathrm{R}}=12.1$ min; syn-enantiomer, $t_{\mathrm{R}}=14.8 \mathrm{~min}$; syn-enantiomer, $t_{\mathrm{R}}=27.8 \mathrm{~min}$.

${ }^{1} \mathrm{H} \mathrm{NMR}\left(300 \mathrm{MHz}, \mathrm{CDCl}_{3}\right): \delta=7.62(\mathrm{~d}, J=8.0 \mathrm{~Hz}, 2 \mathrm{H}), 7.50-7.34(\mathrm{~m}, 8$ H), 7.22-7.13 (m, $3 \mathrm{H}) 7.13-7.08$ ( $\mathrm{m}, 1 \mathrm{H}), 5.46$ (d, J = 6.8 Hz, $1 \mathrm{H}$, syn), $5.36(\mathrm{~d}, J=9.1 \mathrm{~Hz}, 1 \mathrm{H}$, anti), $4.13(\mathrm{~d}, J=9.1 \mathrm{~Hz}, 1 \mathrm{H}$, anti), $4.14(\mathrm{~d}$, $J=6.7 \mathrm{~Hz}, 1 \mathrm{H}$, syn), 3.17 (s, $1 \mathrm{H}$, anti), 2.68 (br, $1 \mathrm{H}$, syn).

${ }^{13} \mathrm{C}$ NMR $\left(75 \mathrm{MHz}, \mathrm{CDCl}_{3}\right.$ ): $\delta=199.1$ (anti), 197.9 (syn), 144.4, 134.5, 134.4, 134.1, 133.4, 130.4, 129.7, 129.5, 129.3, 128.9, 128.5, 128.2, 127.2, 126.9, 125.9, 125.0, 124 (q, J = 270 Hz), 76.1, 74.6, 67.5, 67.2.

${ }^{19} \mathrm{~F} \mathrm{NMR}\left(282 \mathrm{MHz}, \mathrm{CDCl}_{3}\right): \delta=-62.96$ (syn), -62.98 (anti).

MS (ESI+): $m / z=425.1[\mathrm{M}+\mathrm{Na}]^{+}$.

\section{S-Phenyl 3-Hydroxy-3-(2-nitrophenyl)-2-phenylpropanethioate} (81)

Thioester 5 (91 mg, $0.4 \mathrm{mmol}, 2$ equiv), catalyst 2 (12 mg, $0.02 \mathrm{mmol}$, 0.1 equiv), 2 -nitrobenzaldehyde ( $30 \mathrm{mg}, 0.2 \mathrm{mmol}, 1$ equiv), $i-\mathrm{Pr}_{2} \mathrm{NEt}$ (517 mg, $4 \mathrm{mmol}, 10$ equiv), $\mathrm{SiCl}_{4}(102 \mathrm{mg}, 0.6 \mathrm{mmol}, 3$ equiv), and anhydrous $\mathrm{CH}_{2} \mathrm{Cl}_{2}(1.3 \mathrm{~mL})$ were used. After workup, the product was purified by flash chromatography on silica gel with hexane-EtOAc (9:1) as eluent. This purification furnished a mixture of syn- and antidiastereoisomers; yield: $51.2 \mathrm{mg}$ (67\%); pale-yellow solid; mp 63-65 ${ }^{\circ} \mathrm{C} ; R_{f}=0.11$ (hexane-EtOAc, 9:1, stained with phosphomolybdic acid).

HPLC: Chiralcel OD-H; eluent: hexane-i-PrOH (9:1); flux: 0.8 $\mathrm{mL} / \mathrm{min}$; detection: $210 \mathrm{~nm}$; minor enantiomer, $t_{\mathrm{R}}=12.7 \mathrm{~min}$; major enantiomer, $t_{\mathrm{R}}=15.4 \mathrm{~min}$.

${ }^{1} \mathrm{H} \mathrm{NMR}\left(300 \mathrm{MHz}, \mathrm{CDCl}_{3}\right): \delta(s y n)=8.00(\mathrm{dd}, J=6.0 \mathrm{~Hz}, 3.5 \mathrm{~Hz}, 1 \mathrm{H})$, 7.51-7.22 (m, $10 \mathrm{H}), 7.10-7.13(\mathrm{~m}, 3 \mathrm{H}), 6.06(\mathrm{~d}, J=3.4 \mathrm{~Hz}, 1 \mathrm{H}), 4.55$ $(\mathrm{d}, J=3.4 \mathrm{~Hz}, 1 \mathrm{H}), 3.60(\mathrm{br}, 1 \mathrm{H})$.

${ }^{13} \mathrm{C}$ NMR $\left(75 \mathrm{MHz}, \mathrm{CDCl}_{3}\right.$ ): $\delta($ syn $)=200.3,147.4,135.5,134.6,132.9$, 132.5, 130.3, 129.8, 129.3, 128.4, 128.4, 128.2, 126.9, 124.3, 69.7, 63.5 . MS (ESI+): $m / z=402.1[\mathrm{M}+\mathrm{Na}]^{+}$.

\section{S-Phenyl 3-Hydroxy-3-(naphthalen-1-yl)-2-phenylpropanethio- ate $(\mathbf{8 m})$}

Thioester 5 (91 mg, $0.4 \mathrm{mmol}, 2$ equiv), catalyst 2 (12 mg, $0.02 \mathrm{mmol}$, 0.1 equiv), 1 -naphthylaldehyde ( $0.2 \mathrm{mmol}, 1$ equiv), $i-\operatorname{Pr}_{2} \mathrm{NEt}(517 \mathrm{mg}$, $4 \mathrm{mmol}, 10$ equiv), $\mathrm{SiCl}_{4}$ (102 $\mathrm{mg}, 0.6 \mathrm{mmol}, 3$ equiv), and anhydrous $\mathrm{CH}_{2} \mathrm{Cl}_{2}(1.3 \mathrm{~mL})$ were used. After workup, the product was purified by flash chromatography on silica gel with hexane-EtOAc (9:1) as eluent. This purification furnished a mixture of syn- and anti-diastereoisomers; yield: $33.6 \mathrm{mg}$ (44\%); pale-yellow solid; mp 40-42 ${ }^{\circ} \mathrm{C}$; $R_{f}=0.11$ (hexane-EtOAc, 9:1, stained with phosphomolybdic acid).

HPLC: Phenomenex Lux-3u cellulose-1 equipped with securityguard filter; eluent: hexane-EtOH (98:2); flux: $0.8 \mathrm{~mL} / \mathrm{min}$; detection: 210 $\mathrm{nm}$; syn-enantiomer, $t_{\mathrm{R}}=18.1 \mathrm{~min}$; syn-enantiomer, $t_{\mathrm{R}}=23.3 \mathrm{~min}$; anti-enantiomer, $t_{\mathrm{R}}=27.1 \mathrm{~min}$; anti-enantiomer, $t_{\mathrm{R}}=34.8 \mathrm{~min}$.

${ }^{1} \mathrm{H}$ NMR (300 MHz, $\left.\mathrm{CDCl}_{3}\right): \delta=8.24(\mathrm{~d}, J=8.4 \mathrm{~Hz}, 1 \mathrm{H}, \mathrm{syn}), 8.18(\mathrm{~m}, 1$ $\mathrm{H}$, anti), $7.94(\mathrm{~d}, J=7.7 \mathrm{~Hz}, 1 \mathrm{H}$, syn), 7.83-7.80 (m, $1 \mathrm{H}$, syn + anti), $7.76(\mathrm{~d}, J=7.7 \mathrm{~Hz}, 1 \mathrm{H}), 7.68-7.20(\mathrm{~m}, 12 \mathrm{H}), 7.16-7.10(\mathrm{~m}, 3 \mathrm{H}), 6.23$ (d, $J=5.6 \mathrm{~Hz}, 1 \mathrm{H}$, syn), 5.98 (d, $J=8.3 \mathrm{~Hz}, 1 \mathrm{H}$, anti), 4.68 (d, $J=8.3 \mathrm{~Hz}$, $1 \mathrm{H}$, anti), $4.51(\mathrm{~d}, J=5.6 \mathrm{~Hz}, 1 \mathrm{H}, \mathrm{syn}), 3.31(\mathrm{br}, 1 \mathrm{H}$, anti), $2.91(\mathrm{br}, 1 \mathrm{H}$, syn).

${ }^{13} \mathrm{C}$ NMR $\left(75 \mathrm{MHz}, \mathrm{CDCl}_{3}\right): \delta=199.4,198.6,135.6,134.9,134.5,134.4$, $133.8,133.6,129.8,129.6,129.2,129.1,128.8,128.6,128.5,128.4$, $128.1,127.8,126.3,126.0,125.5,125.3,125.2,125.0,123.5,122.9$, 75.0, 71.7, 65.8, 65.4 .

MS (ESI+): $m / z=407.1[\mathrm{M}+\mathrm{Na}]^{+}$.

\section{S-Phenyl 3-(Furan-2-yl)-3-hydroxy-2-phenylpropanethioate (8n)}

Thioester 5 ( $91 \mathrm{mg}, 0.4 \mathrm{mmol}, 2$ equiv), catalyst 2 (12 mg, $0.02 \mathrm{mmol}$, 0.1 equiv), furan-2-carbaldehyde ( $19 \mathrm{mg}, 0.2 \mathrm{mmol}, 1$ equiv), $i-\mathrm{Pr}_{2} \mathrm{NEt}$ (517 mg, $4 \mathrm{mmol}, 10$ equiv), $\mathrm{SiCl}_{4}$ (102 mg, $0.6 \mathrm{mmol}, 3$ equiv), and anhydrous $\mathrm{CH}_{2} \mathrm{Cl}_{2}(1.3 \mathrm{~mL})$ were used. After workup, the product was purified by flash chromatography on silica gel with hexane-EtOAc (9:1) as eluent. This purification furnished a mixture of syn- and antidiastereoisomers; yield: $49.1 \mathrm{mg}$ (76\%); pale-yellow solid; mp 77-79 ${ }^{\circ} \mathrm{C} ; R_{f}=0.10$ (hexane-EtOAc, 9:1, stained with phosphomolybdic acid).

HPLC: Phenomenex Lux-3u cellulose-1 equipped with securityguard filter; eluent: hexane-i-PrOH (95:5); flux: $0.8 \mathrm{~mL} / \mathrm{min}$; detection: $210 \mathrm{~nm}$; anti-enantiomer, $t_{\mathrm{R}}=7.0 \mathrm{~min}$; syn-enantiomer, $t_{\mathrm{R}}=8.7 \mathrm{~min}$; anti-enantiomer; $t_{\mathrm{R}}=11.3 \mathrm{~min}$; syn-enantiomer, $t_{\mathrm{R}}=14.2 \mathrm{~min}$.

${ }^{1} \mathrm{H}$ NMR $\left(300 \mathrm{MHz}, \mathrm{CDCl}_{3}\right.$ ): $\delta=7.48-7.33(\mathrm{~m}, 9 \mathrm{H}), 7.28(\mathrm{~s}, 2 \mathrm{H}), 6.35$ (d, $J=15.0 \mathrm{~Hz}, 2 \mathrm{H}$ ), 6.14 (d, $J=40.6 \mathrm{~Hz}, 2 \mathrm{H}$, overlapping signals), 5.41 (d, J = 8.0 Hz, $1 \mathrm{H}$, syn), 5.32 (d, $J=8.8 \mathrm{~Hz}, 1 \mathrm{H}$, anti), 4.53 (d, $J=9.0 \mathrm{~Hz}$, $1 \mathrm{H}$, anti), 4.46 (d, J = 8.1 Hz, $1 \mathrm{H}$, syn), $3.00(\mathrm{br}, 1 \mathrm{H}), 2.34(\mathrm{br}, 1 \mathrm{H})$.

${ }^{13} \mathrm{C}$ NMR $\left(75 \mathrm{MHz}, \mathrm{CDCl}_{3}\right): \delta=197.0,153.0,142.4,134.4,134.1,129.6$, $129.3,129.2,129.0,128.8,128.6,128.4,128.0,127.2,110.4,110.1$, $108.1,70.2,69.1,64.5$.

MS (ESI+): $m / z=347.1[\mathrm{M}+\mathrm{Na}]^{+}$.

\section{S-Phenyl 2-(4-Fluorophenyl)-3-hydroxy-3-phenylpropanethioate (10a)}

Thioester 9a (148 mg, $0.6 \mathrm{mmol}, 2$ equiv), catalyst 1 (18 mg, 0.03 mmol, 0.1 equiv), benzaldehyde ( $32 \mathrm{mg}, 0.3 \mathrm{mmol}, 1$ equiv), $i-\mathrm{Pr}_{2} \mathrm{NEt}$ ( $775 \mathrm{mg}, 6 \mathrm{mmol}, 10$ equiv), $\mathrm{SiCl}_{4}$ ( $153 \mathrm{mg}, 0.9 \mathrm{mmol}, 3$ equiv), and anhydrous $\mathrm{CH}_{2} \mathrm{Cl}_{2}(2 \mathrm{~mL})$ were used. After workup, the product was purified by flash chromatography on silica gel with hexane-EtOAc (9:1) as eluent. This purification furnished a mixture of syn- and antidiastereoisomers; yield: $46.5 \mathrm{mg}(44 \%)$; white solid; mp $106-108{ }^{\circ} \mathrm{C}$; $R_{f}=0.13$ (hexane-EtOAc, 9:1, stained with phosphomolybdic acid). 
HPLC: Phenomenex Lux-3u cellulose 4; eluent: hexane-EtOH (98:2); flux: $0.8 \mathrm{~mL} / \mathrm{min}$; detection: $210 \mathrm{~nm}$; syn-enantiomer, $t_{\mathrm{R}}=3.6 \mathrm{~min}$; syn-enantiomer, $t_{\mathrm{R}}=4.6 \mathrm{~min}$; anti-enantiomer, $t_{\mathrm{R}}=5.4 \mathrm{~min}$; anti-enantiomer, $t_{\mathrm{R}}=7.0 \mathrm{~min}$.

${ }^{1} \mathrm{H}$ NMR (300 MHz, $\mathrm{CDCl}_{3}$ ): $\delta=7.40-7.00(\mathrm{~m}, 14 \mathrm{H}), 5.35(\mathrm{dd}, J=1.8$, $6.7 \mathrm{~Hz}, 1 \mathrm{H}$, syn), 5.23 (dd, $J=2.3,9.2 \mathrm{~Hz}, 1 \mathrm{H}$, anti), 4.17 (d, $J=9.2 \mathrm{~Hz}$, $1 \mathrm{H}$, anti), 4.13 (d, J = 6.7 Hz, $1 \mathrm{H}$, syn), 2.89 (br, $1 \mathrm{H}$, anti), 2.51 (br, $1 \mathrm{H}$, syn).

${ }^{13} \mathrm{C}$ NMR (75 MHz, $\mathrm{CDCl}_{3}$ ): $\delta=198.89$ (anti), 198.0 (syn), 162.7 (d, $J=247.2 \mathrm{~Hz}$ ), 140.4, 134.5, 134.4, 131.2, 131.1, 130.5, 129.8, 129.7, $129.2,128.3,128.2,128.1,127.3,127.0,126.7,126.6,115.8,115.5$, 75.2, 66.5 .

${ }^{19} \mathrm{~F} \operatorname{NMR}\left(282 \mathrm{MHz}, \mathrm{CDCl}_{3}\right.$ ): $\delta=-114.37$ (syn), -114.49 (anti).

MS (ESI+): $m / z=375.1[\mathrm{M}+\mathrm{Na}]^{+}$

\section{S-Phenyl 3-Hydroxy-2-(4-isobutylphenyl)-3-phenylpropanethio- ate (10b)}

Thioester 9b (1.70 g, $0.6 \mathrm{mmol}, 2$ equiv), catalyst 2 (19 mg, 0.03 mmol, 0.1 equiv), benzaldehyde ( $32 \mathrm{mg}, 0.3 \mathrm{mmol}, 1$ equiv), $i-\mathrm{Pr}_{2} \mathrm{NEt}$ ( $775 \mathrm{mg}, 6 \mathrm{mmol}, 10$ equiv), $\mathrm{SiCl}_{4}$ (153 $\mathrm{mg}, 0.9 \mathrm{mmol}, 3$ equiv), and anhydrous $\mathrm{CH}_{2} \mathrm{Cl}_{2}(2 \mathrm{~mL})$ were used. After workup, the product was purified by flash chromatography on silica gel with hexane-EtOAc (95:5) as eluent. This purification furnished a mixture of syn- and anti-diastereoisomers; yield: $55.0 \mathrm{mg}$ (47\%); white solid; mp 88-90 ${ }^{\circ} \mathrm{C} ; R_{f}=0.31$ (syn), $R_{f}=0.23$ (anti) (hexane-EtOAc, 9:1, stained with phosphomolybdic acid).

HPLC: (syn-isomer) Chiralcel OD-H; eluent: hexane- $i$-PrOH (8:2); flux: $0.8 \mathrm{~mL} / \mathrm{min}$; detection: $210 \mathrm{~nm}$; minor enantiomer, $t_{\mathrm{R}}=9.7$; major enantiomer, $t_{\mathrm{R}}=11.5 \mathrm{~min}$; (anti-isomer) Chiralcel OD-H; eluent: hexane- $i$-PrOH (8:2); flux: $0.8 \mathrm{~mL} / \mathrm{min}$; detection: $210 \mathrm{~nm}$; major enantiomer, $t_{\mathrm{R}}=11.8 \mathrm{~min}$; minor enantiomer, $t_{\mathrm{R}}=13.8 \mathrm{~min}$.

${ }^{1} \mathrm{H}$ NMR (300 MHz, $\left.\mathrm{CDCl}_{3}\right): \delta($ syn $)=7.40-7.30(\mathrm{~m}, 10 \mathrm{H}), 7.28-7.15$ (m, $4 \mathrm{H}), 5.35$ (d, J=7.5 Hz, $1 \mathrm{H}), 4.12(\mathrm{~d}, J=7.6 \mathrm{~Hz}, 1 \mathrm{H}), 2.44$ (d, $J=7.2 \mathrm{~Hz}, 2 \mathrm{H}), 1.97-1.81(\mathrm{~m}, 1 \mathrm{H}), 0.94(\mathrm{~d}, J=6.6 \mathrm{~Hz}, 3 \mathrm{H}), 0.93$ (d, $J=6.6 \mathrm{~Hz}, 3 \mathrm{H}) ; \delta($ anti $)=7.42-7.38(\mathrm{~m}, 5 \mathrm{H}), 7.28-7.18(\mathrm{~m}, 3 \mathrm{H})$, 7.15-7.08 (m, $2 \mathrm{H}), 7.00(\mathrm{~s}, 4 \mathrm{H}) 5.28(\mathrm{~d}, J=7.5 \mathrm{~Hz}, 1 \mathrm{H}), 4.15(\mathrm{~d}, J=7.5$ $\mathrm{Hz}, 1 \mathrm{H}), 2.42(\mathrm{~d}, J=7.2 \mathrm{~Hz}, 2 \mathrm{H}), 1.97-1.81(\mathrm{~m}, 1 \mathrm{H}), 0.88(\mathrm{~d}, J=6.6 \mathrm{~Hz}$, $3 \mathrm{H}), 0.85$ (d, $J=6.6 \mathrm{~Hz}, 3 \mathrm{H})$.

${ }^{13} \mathrm{C}$ NMR $\left(75 \mathrm{MHz}, \mathrm{CDCl}_{3}\right)$ : $\delta($ syn $)=199.3,141.4,140.8,134.5,131.9$, 129.5, 129.4, 129.2, 128.6, 128.0, 127.7, 127.6, 126.5, 76.8, 67.5, 45.0, 30.1, 22.3.

MS (ESI+): $m / z=413.2[\mathrm{M}+\mathrm{Na}]^{+}$.

\section{$S$-Phenyl 3-Hydroxy-2-(4-isobutylphenyl)-3-(4-methoxyphe- nyl)propanethioate (10c)}

Thioester 9b (1.70 g, $0.6 \mathrm{mmol}, 2$ equiv), catalyst 2 (19 mg, 0.03 mmol, 0.1 equiv), 4-methoxybenzaldehyde (41 $\mathrm{mg}, 0.3 \mathrm{mmol}, 1$ equiv), $i-\mathrm{Pr}_{2} \mathrm{NEt}$ ( $775 \mathrm{mg}, 6 \mathrm{mmol}, 10$ equiv), $\mathrm{SiCl}_{4}$ (153 mg, $0.9 \mathrm{mmol}$, 3 equiv), and anhydrous $\mathrm{CH}_{2} \mathrm{Cl}_{2}(2 \mathrm{~mL})$ were used. After workup, the product was purified by flash chromatography on silica gel with hexane-EtOAc (85:15) as eluent. This purification furnished a mixture of syn- and anti-diastereoisomers; yield: $54.3 \mathrm{mg}$ (43\%); white solid; mp $81-83{ }^{\circ} \mathrm{C} ; R_{f}=0.10$ (hexane-EtOAc, $97: 3$, stained with phosphomolybdic acid).

HPLC: Chiralcel OD-H; eluent: hexane-i-PrOH (9:1); flux: 0.8 $\mathrm{mL} / \mathrm{min}$; detection: $210 \mathrm{~nm}$; syn-enantiomer, $t_{\mathrm{R}}=12.6 \mathrm{~min}$; syn-enantiomer, $t_{\mathrm{R}}=14.3 \mathrm{~min}$; anti-enantiomer, $t_{\mathrm{R}}=16.2 \mathrm{~min}$; anti-enantiomer, $t_{\mathrm{R}}=18.5 \mathrm{~min}$.
${ }^{1} \mathrm{H}$ NMR $\left(300 \mathrm{MHz}, \mathrm{CDCl}_{3}\right): \delta=7.27-7.38(\mathrm{~m}, 7 \mathrm{H}), 7.28-7.18(\mathrm{~m}, 4 \mathrm{H})$, $6.90(\mathrm{~d}, J=8.7 \mathrm{~Hz}, 2 \mathrm{H}, s y n), 6.71(\mathrm{~d}, J=8.7 \mathrm{~Hz}, 2 \mathrm{H}$, anti), 5.30 (d, $J=7.8 \mathrm{~Hz}, 1 \mathrm{H}$, syn $), 5.23(\mathrm{~d}, J=9.1 \mathrm{~Hz}, 1 \mathrm{H}$, anti), $4.12(\mathrm{~d}, J=9.1 \mathrm{~Hz}, 1$ $\mathrm{H}$, anti), 4.10 (d, J= 7.8 Hz, $1 \mathrm{H}$, syn), $3.84(\mathrm{~s}, 3 \mathrm{H}$, syn), 2.50 (d, $J=7.8$ $\mathrm{Hz}, 2 \mathrm{H}, \mathrm{syn}$ ), 2.40 (d, J = 7.8 Hz, $2 \mathrm{H}$, anti), 1.97-1.78 (m, $1 \mathrm{H}), 0.94$ (d, $J=6.60 \mathrm{~Hz}, 3 \mathrm{H}$, syn + anti), $0.93(\mathrm{~d}, J=6.60 \mathrm{~Hz}, 3 \mathrm{H}, \mathrm{syn}+$ anti), 0.88 (d, $J=6.60 \mathrm{~Hz}, 3 \mathrm{H}$, syn + anti).

${ }^{13} \mathrm{C}$ NMR $\left(75 \mathrm{MHz}, \mathrm{CDCl}_{3}\right.$ ): $\delta=197.6,159.4,141.8,134.4,132.8,131.5$, 129.6, 129.4, 129.1, 129.0, 128.1, 127.3, 113.7, 75.1, 67.6, 55.3, 45.1, 30.1, 22.4.

MS (ESI+): $m / z=443.2[\mathrm{M}+\mathrm{Na}]^{+}$.

\section{S-Phenyl 3-Hydroxy-2-(4-isobutylphenyl)-3-(4-chlorophenyl)pro- panethioate (10d)}

Thioester 9b (1.70 g, $0.6 \mathrm{mmol}, 2$ equiv), catalyst 2 (19 mg, 0.03 mmol, 0.1 equiv), 4-chlorobenzaldehyde ( $42 \mathrm{mg}, 0.3 \mathrm{mmol}, 1$ equiv), $i$ - $\mathrm{Pr}_{2} \mathrm{NEt}$ ( $775 \mathrm{mg}, 6 \mathrm{mmol}, 10$ equiv), $\mathrm{SiCl}_{4}(153 \mathrm{mg}, 0.9 \mathrm{mmol}, 3$ equiv), and anhydrous $\mathrm{CH}_{2} \mathrm{Cl}_{2}(2 \mathrm{~mL})$ were used. After workup, the product was purified by flash chromatography on silica gel with hexane-EtOAc (97:3) as eluent. This purification furnished isolated synand anti-diastereoisomers; yield: $75.2 \mathrm{mg}$ (59\%); white solid; $\mathrm{mp}$ 103-105 ${ }^{\circ} \mathrm{C} ; R_{f}=0.22$ (syn), $R_{f}=0.14$ (anti) (hexane-EtOAc, 97:3, stained with phosphomolybdic acid).

HPLC: Chiralcel OD-H; eluent: hexane- $i-\mathrm{PrOH}$ (9:1); flux: 0.8 $\mathrm{mL} / \mathrm{min}$; detection: $210 \mathrm{~nm}$; syn-enantiomer, $t_{\mathrm{R}}=10.0 \mathrm{~min}$; syn-enantiomer, $t_{\mathrm{R}}=12.4 \mathrm{~min}$; anti-enantiomer, $t_{\mathrm{R}}=14.2 \mathrm{~min}$; anti-enantiomer, $t_{\mathrm{R}}=15.4 \mathrm{~min}$.

${ }^{1} \mathrm{H}$ NMR $\left(300 \mathrm{MHz}, \mathrm{CDCl}_{3}\right): \delta($ syn $)=7.43-6.99(\mathrm{~m}, 13 \mathrm{H}), 5.31(\mathrm{~d}$, $J=7.2 \mathrm{~Hz}, 1 \mathrm{H}$ ), 4.03 (d, J= 7.2 Hz, $1 \mathrm{H}), 2.48$ (d, $J=7.1 \mathrm{~Hz}, 2 \mathrm{H}), 1.88$ $(\mathrm{m}, 1 \mathrm{H}), 0.92(\mathrm{~d}, J=6.6 \mathrm{~Hz}, 6 \mathrm{H}) ; \delta($ anti $)=7.45-7.34(\mathrm{~m}, 4 \mathrm{H}), 7.13(\mathrm{~d}$, $J=8.3 \mathrm{~Hz}, 2 \mathrm{H}$ ), 7.01-6.95 (m, $7 \mathrm{H}), 5.23(\mathrm{~d}, J=9.1 \mathrm{~Hz}, 1 \mathrm{H}), 4.06$ (d, $J=9.1 \mathrm{~Hz}, 1 \mathrm{H}), 3.03$ (br, $1 \mathrm{H}), 2.41$ (d, J = 7.2 Hz, $2 \mathrm{H}$ ), 1.88-1.69 (m, 1 $\mathrm{H}), 8.86(\mathrm{~d}, J=6.6 \mathrm{~Hz}, 6 \mathrm{H})$.

${ }^{13} \mathrm{C}$ NMR $\left(75 \mathrm{MHz}, \mathrm{CDCl}_{3}\right.$ ): $\delta=197.6,141.8,138.8,134.4,134.1,133.4$, 130.5, 129.3, 128.9, 128.1, 128.0, 126.8, 74.3, 66.9, 44.8, 29.8, 22.1.

MS (ESI+): $m / z=447.3[\mathrm{M}+\mathrm{Na}]^{+}$.

\section{S-Benzyl 3-Hydroxy-2,3-diphenylpropanethioate (12)}

Thioester 11 ( $145 \mathrm{mg}, 2$ equiv, $0.6 \mathrm{mmol}$ ), catalyst 2 (19 mg, 0.1 equiv, $0.03 \mathrm{mmol}$ ), benzaldehyde ( $32 \mathrm{mg}, 0.3 \mathrm{mmol}, 1$ equiv), $i-\mathrm{Pr}_{2} \mathrm{NEt}(775$ $\mathrm{mg}, 6 \mathrm{mmol}, 10$ equiv), $\mathrm{SiCl}_{4}$ (153 mg, $0.9 \mathrm{mmol}, 3$ equiv), and anhydrous $\mathrm{CH}_{2} \mathrm{Cl}_{2}(2 \mathrm{~mL})$ were used. After workup, the product was purified by flash chromatography on silica gel with hexane-EtOAc- $\mathrm{CH}_{2} \mathrm{Cl}_{2}$ (9:0.5:0.5) as eluent. This purification furnished a mixture of syn- and anti-diastereoisomers; yield: $30.3 \mathrm{mg}$ (29\%); white solid; mp 81-83 ${ }^{\circ} \mathrm{C} ; R_{f}=0.18$ (hexane-EtOAc, 9:1, stained with phosphomolybdic acid).

HPLC: Chiralcel OD-H; eluent: hexane- $i-\operatorname{PrOH}$ (9:1); flux: 0.8 $\mathrm{mL} / \mathrm{min}$; detection: $230 \mathrm{~nm}$; anti-enantiomer, $t_{\mathrm{R}}=14.4 \mathrm{~min}$; syn-enantiomer, $t_{\mathrm{R}}=16.6 \mathrm{~min}$; syn-enantiomer, $t_{\mathrm{R}}=20.4 \mathrm{~min}$; anti-enantiomer, $t_{\mathrm{R}}=30.8 \mathrm{~min}$.

${ }^{1} \mathrm{H} \mathrm{NMR}\left(300 \mathrm{MHz}, \mathrm{CDCl}_{3}\right): \delta=7.39-7.06(\mathrm{~m}, 15 \mathrm{H}), 5.38(\mathrm{~d}, J=6.0 \mathrm{~Hz}$, $1 \mathrm{H}$, syn), 5.30 (d, J = 6.0 Hz, $1 \mathrm{H}$, anti), $4.22(\mathrm{~d}, J=13.8 \mathrm{~Hz}, 1 \mathrm{H}$, anti), $4.13(\mathrm{~d}, J=13.8 \mathrm{~Hz}, 1 \mathrm{H}, \mathrm{syn}), 4.13-4.02(\mathrm{~m}, 3 \mathrm{H}), 3.87$ (d, $J=14.0 \mathrm{~Hz}, 1$ $\mathrm{H}$, anti).

${ }^{13} \mathrm{C}$ NMR $\left(75 \mathrm{MHz}, \mathrm{CDCl}_{3}\right.$ ): $\delta=200.1$ (anti), 198.5 (syn), 140.5 (syn), 140.7 (syn), 140.5 (anti), 136.8, 134.9 (anti), 134.4 (syn), 129.3, 128.8, 128.7, 128.6, 128.5, 128.3, 128.2, 128.1, 128.0, 127.9, 127.8, 127.3, 127.2, 126.8, 126.6, 75.2, 67.9 (syn), 67.8 (anti), 33.7 (anti), 33.3 (syn). 
MS (ESI+): $m / z=371.2[\mathrm{M}+\mathrm{Na}]^{+}$.

\section{Acknowledgment}

S.R. thanks Università degli Studi di Milano for a postdoctoral fellowship.

\section{Supporting Information}

Supporting information for this article is available online at http://dx.doi.org/10.1055/s-0034-1379914.

\section{References}

(1) (a) Denmark, S. E.; Beutner, G. L. Angew. Chem. Int. Ed. 2008, 47, 1560. (b) Kotani, S.; Sugiura, M.; Nakajima, M. Chem. Rec. 2013, 13, 362. (c) Rossi, S.; Benaglia, M.; Genoni, A. Tetrahedron 2014, 70, 2065. (d) Benaglia, M.; Guizzetti, S.; Rossi, S. In Catalytic Methods in Asymmetric Synthesis; Gruttadauria, M.; Giacalone, F., Eds.; Wiley-VCH: Weinheim, 2011, 579-624.

(2) (a) Tandura, S.; Voronkov, M.; Alekseev, N. Top. Curr. Chem. 1985, 131, 99. (b) Corriu, R. J. P.; Young, J. C. In The Silicon-Heteroatom Bond; Patai, S.; Rappoport, Z., Eds.; Wiley: New York, 1991, 1-48. (c) Feshin, V. P.; Feshina, E. V. Russ. J. Gen. Chem. 2007, 77, 2123. (d) Hosomi, A. Acc. Chem. Res. 1988, 21, 200. (e) Furin, G. G.; Vyazankina, O. A.; Gostevsky, B. A.; Vyazankin, N. S. Tetrahedron 1988, 44, 2675. (f) Kost, D.; Kalikhman, I. Adv. Organomet. Chem. 2004, 50, 1. (g) Kost, D.; Kalikhman, I. Acc. Chem. Res. 2008, 42, 303. (h) Benaglia, M.; Guizzetti, S.; Pignataro, L. Coord. Chem. Rev. 2008, 252, 492.

(3) (a) Enantioselective Organocatalysis. Reactions and Experimental Procedures; Dalko, P. I., Ed.; Wiley-VCH: Weinheim, 2007. (b) Asymmetric Organocatalysis, In Topics in Current Chemistry; Vol. 291; List, B., Ed.; Springer: Berlin, 2009, 1-347.

(4) (a) Rendler, S.; Oestreich, M. Synthesis 2005, 1727. (b) Jensen, W. B. J. Chem. Educ. 2006, 83, 1751.

(5) (a) Denmark, S. E.; Eklov, B. M.; Yao, P. J.; Eastgate, M. D. J. Am. Chem. Soc. 2009, 131, 11770. (b) Denmark, S. E.; Wilson, T. W. Nat. Chem. 2010, 2, 937. (c) Denmark, S. E.; Wilson, T. W. Angew. Chem. Int. Ed. 2012, 51, 3236.

(6) Review: (a) Benaglia, M.; Rossi, S. Org. Biomol. Chem. 2010, 8, 3824. (b) See also: Kotani, S.; Shimoda, Y.; Sugiura, M.; Nakajima, M. Tetrahedron Lett. 2009, 50, 4602. (c) Rossi, S.; Benaglia, M.; Genoni, A.; Benincori, T.; Celentano, G. Tetrahedron 2011, 67, 158.

(7) Massa, A.; Capozzolo, L.; Scettri, A. Cent. Eur. J. Chem. 2010, 8, 1210.
(8) (a) Rossi, S.; Benaglia, M.; Cozzi, F.; Genoni, A.; Benincori, T. Adv. Synth. Catal. 2011, 353, 848. (b) Bonsignore, M.; Benaglia, M.; Cozzi, F.; Genoni, A.; Rossi, S.; Raimondi, L. Tetrahedron 2012, 68, 8251.

(9) For examples of thioesters in Mannich reactions, see: (a) Ricci, A.; Pettersen, D.; Bernardi, L.; Fini, F.; Fochi, M.; Herrera, R. P.; Sgarzani, V. Adv. Synth. Catal. 2007, 349, 1037. (b) Utsumi, N.; Kitagaki, S.; Barbas, C. F. III Org. Lett. 2008, 10, 3405. (c) Bahlinger, A.; Fritz, S. P.; Wennemers, H. Angew. Chem. Int. Ed. 2014, 53, 8779. For examples of thioesters in Michael reactions, see: (d) Alonso, D. A.; Kitagaki, S.; Utsumi, N.; Barbas, C. F. III Angew. Chem. Int. Ed. 2008, 47, 4588.

(10) For examples of malonic acid half thioesters in Mannich reactions, see: (a) Pan, Y.; Kee, C. W.; Jiang, Z.; Ma, T.; Zhao, Y.; Yang, Y.; Xue, H.; Tan, C.-H. Chem. Eur. J. 2011, 17, 8363. (b) Zhong, F.; Jiang, C.; Yao, W.; Xu, L.-W.; Lu, Y. Tetrahedron Lett. 2013, 54, 4333. For examples of malonic acid half thioesters in Michael reactions, see: (c) Lubkoll, J.; Wennemers, H. Angew. Chem. Int. Ed. 2007, 46, 6841. (d) Arakawa, Y.; Fritz, S. P.; Wennemers, H. J. Org. Chem. 2014, 79, 3937.

(11) (a) Di Mola, A.; Massa, A. Curr. Org. Chem. 2012, 16, 2290. (b) More, V.; Di Mola, A.; Croce, G.; Tedesco, C.; Petronzi, C.; Peduto, A.; De Caprariis, P.; Filosa, R.; Massa, A. Org. Biomol. Chem. 2011, 9, 8483. (c) Massa, A.; Roscigno, A.; De Caprariis, P.; Filosa, R.; Di Mola, A. Adv. Synth. Catal. 2010, 352, 3348. (d) Massa, A.; Scettri, A.; Filosa, R.; Capozzolo, L. Tetrahedron Lett. 2009, 50, 7318.

(12) Bae, H. Y.; Sim, J. H.; Lee, J. W.; List, B.; Song, C. E. Angew. Chem. Int. Ed. 2013, 52, 12143.

(13) Ren, Q.; Sun, S.; Huang, J.; Li, W.; Wu, M.; Guo, H.; Wang, J. Chem. Commun. 2014, 50, 6137.

(14) Bordwell, F. G.; Fried, H. E. J. Org. Chem. 1991, 56, 4218.

(15) Beattie, I. R.; Leigh, G. J. J. Inorg. Nucl. Chem. 1961, 23, 55.

(16) A typical procedure for the enantioselective direct aldol reaction involves the use of 2 equiv of thioester, 1 equiv of aldehyde, 3 equiv of freshly distilled $\mathrm{SiCl}_{4}, 10$ equiv of $i-\mathrm{Pr}_{2} \mathrm{NEt}$, and 10 mol\% of catalyst in $\mathrm{CH}_{2} \mathrm{Cl}_{2}$ as solvent.

(17) Denmark, S. E.; Wynn, T.; Beutner, G. L. J. Am. Chem. Soc. 2002, $124,13405$.

(18) Minato, H.; Kodama, H.; Miura, T.; Kobayashi, M. Chem. Lett. 1977, 413.

(19) (a) Ramachandran, P. V.; Chanda, P. B. Chem. Commun. 2013, 49, 3152. (b) Fringuelli, F.; Piermatti, O.; Pizzo, F. J. Org. Chem. 1995, 60, 7006.

(20) (a) Gennari, C.; Beretta, M. G.; Bernardi, A.; Moro, G.; Scolastico, C.; Todeschini, R. Tetrahedron 1986, 42, 893. (b) Wilcox, C. S.; Babston, R. E.J. Org. Chem. 1984, 49, 1451.

(21) Zimmerman, H. E.; Traxler, M. D. J. Am. Chem. Soc. 1957, 79, 1920.

(22) Schrödinger Release 2014-3: MacroModel, Version 10.5; Schrödinger LLC: New York, 2014.

(23) Stewart, J. J. P. J. Mol. Model. 2007, 13, 1173. 